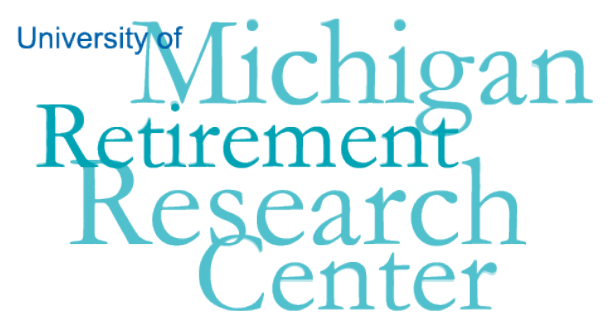

Working Paper WP 2013-293

\title{
How Family Status and Social Security Claiming Options Shape Optimal Life Cycle Portfolios
}

\author{
Andreas Hubener, Raimond Maurer, and Olivia S. Mitchell
}

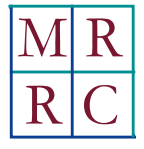

Project \#: UM13-12 



\title{
How Family Status and Social Security Claiming Options Shape Optimal Life Cycle Portfolios
}

\author{
Andreas Hubener \\ Goethe University of Frankfurt \\ Raimond Maurer \\ Goethe University of Frankfurt \\ Olivia S. Mitchell \\ The Wharton School, University of Pennsylvania
}

October 2013

Michigan Retirement Research Center

University of Michigan

P.O. Box 1248

Ann Arbor, MI 48104

www.mrrc.isr.umich.edu

(734) 615-0422

\section{Acknowledgements}

This work was supported by a grant from the Social Security Administration through the Michigan Retirement Research Center (Grant \# 5 RRC08098401-05-00). The findings and conclusions expressed are solely those of the author and do not represent the views of the Social Security Administration, any agency of the Federal government, or the Michigan Retirement Research Center.

\section{Regents of the University of Michigan}

Mark J. Bernstein, Ann Arbor; Julia Donovan Darlow, Ann Arbor; Laurence B. Deitch, Bloomfield Hills; Shauna Ryder Diggs, Grosse Pointe; Denise Ilitch, Bingham Farms; Andrea Fischer Newman, Ann Arbor; Andrew C. Richner, Grosse Pointe Park ;

Katherine E. White, Ann Arbor; Mary Sue Coleman, ex officio 


\title{
How Family Status and Social Security Claiming Options Shape Optimal Life Cycle Portfolios
}

\begin{abstract}
Household decisions are profoundly shaped by a complex set of financial options due to Social Security rules determining retirement, spousal, and survivor benefits, along with benefit adjustments that vary with the age at which these are claimed. These rules influence optimal household asset allocation, insurance, and work decisions, given life cycle demographic shocks such as marriage, divorce, and children. Our model generates a wealth profile and a low and stable equity fraction consistent with empirical evidence. We also confirm predictions that wives will claim retirement benefits earlier than husbands, while life insurance is mainly purchased by younger men. Our policy simulations imply that eliminating survivor benefits would sharply reduce claiming differences by sex while dramatically increasing men’s life insurance purchases.
\end{abstract}

\section{Citation}

Hubener, Andreas, Raimond Maurer, and Olivia S. Mitchell (2013). "How Family Status and Social Security Claiming Options Shape Optimal Life Cycle Portfolios.” Ann Arbor MI: University of Michigan Retirement Research Center (MRRC) Working Paper, WP 2013-293.

http://www.mrrc.isr.umich.edu/publications/papers/pdf/wp293.pdf

\section{Authors’ Acknowledgements}

The research reported herein was performed pursuant to a grant from the US Social Security Administration to the Michigan Retirement Research Center as part of the Retirement Research Consortium. Additional research support was provided by the Deutsche Forschungsgemeinschaft, the German Investment and Asset Management Association (BVI), the Pension Research Council/Boettner center at The Wharton School of the University of Pennsylvania, the Metzler Exchange Professor program, and the Eunice Shriver Kennedy National Institute of Child Health and Development Population Research Infrastructure Program R24 HD044964-10 at the University of Pennsylvania. The authors thank David Love, Sita Slavov, Karen Smith, and John Shoven for generously sharing data and computer code; Yong Yu for excellent programming assistance; and James Anderson for research assistance. Opinions and errors are solely those of the authors and not of the institutions with whom the authors are affiliated. (c) 2013 Hubener, Maurer, and Mitchell. All rights reserved. 


\section{How Family Status and Social Security Claiming Options Shape Optimal Life Cycle Portfolios}

\section{Introduction}

Two crucial factors drive households' optimal life cycle saving and investment decisions: labor market work and family status. This is because decisions about hours of work as well as retirement ages shape labor earnings, which in turn influence how people spend, save, invest, and build up retirement benefits through the Social Security system. Not only are wages uncertain, but so too is family status due to marriage/divorce, the arrival/departure of children, and spousal death. Each of these poses fundamentally important risks to the household's financial position: for instance, the arrival of children shape household spending and saving patterns due to child support in the case of marital splits and college costs. Not only do children influence finances directly; they also change the amount of time that household members, especially mothers, can earn income essential to build up financial assets (Kimmel and Connelly, 2007).

Also key to life cycle decisions is the role of the Social Security system. In the United States, this is a national mandatory deferred life annuity scheme with complex claiming options and cash-flow patterns that depend on age, work history, and family status. Social Security is especially crucial because it represents such a large component of household assets. For example, the median Baby Boomer household on the verge of retirement has accumulated $\$ 600,000$, of which 40 percent is Social Security wealth; and the remainder is divided evenly between home equity, non-pension financial assets, and pension wealth. ${ }^{1}$ The risk and return profile of this important asset should therefore have profound consequences for how households manage their financial wealth, both during the work life and in retirement. And it is increasingly becoming clear that when to exercise the option to claim Social Security benefits is one of the most crucial and complex financial decisions facing workers. For example, claiming benefits at age 70 instead of age 62 boosts lifelong payments by 76 percent (Myers, 1985). Additionally, the financial decision of when to claim Social Security benefits is different from, but also related to, the decision about when to leave the labor force (c.f., Coile et al., 2002). For example, workers can retire early at age 62, delay claiming until age 70 to boost benefits, and draw down financial assets to maintain

\footnotetext{
${ }^{1}$ This measure (in \$2010) includes financial assets, home equity, business and pension assets, and Social Security benefits, and it nets out financial and mortgage debt (see Gustman et al., 2010).
} 
consumption. Or they can claim at the earliest possible age 62 by accepting lower benefits, continue to work, and concurrently receive income from work and Social Security benefits.

The Social Security system offers a complex set of family benefits which also shapes optimal financial wealth and claiming patterns. Thus couples build up an entitlement to their own old age retirement benefits over their working lives, as well as spousal and widow(er) benefits that depend on the partners' work histories. Moreover, the Social Security rules permit individuals to first claim old age benefits on their own work records, and later switch to spousal/widow benefits. In other words, the decision about when to claim benefits depends intimately on family status; in turn, the claiming age has a large effect on payouts to spouses and survivors. Thus these family benefits can have a pronounced effect on saving and investment decisions including the demand for risky stocks and life insurance products. For this reason, theoretical analysis of the claiming dynamics and the influence of Social Security benefits on financial wealth management requires examining a full household optimization framework over the complete life cycle which jointly models the work, saving, investment, and claiming decisions. Until now, such a model has not been available in the literature.

This paper incorporates these key elements of the household life cycle - Social Security benefits and family dynamics - into a realistically-calibrated portfolio and consumption choice life cycle model in discrete time with forward-looking rational multiperson households. We allow for risky asset returns as well as uncertainty in family status, mortality, labor income, and retirement income. Using data from the Panel Study of Income Dynamics (PSID), we calibrate wage rate dynamics by age, sex, education, and family status. In addition we calibrate the impact of child care time on the households' available budget for income generating work hours using the American Time Use Survey (ATUS). We track the individual work history for each spouse separately and realistically model Social Security old age benefits with spousal and survivor benefits as well as delayed claiming options. In this environment, an individual makes decisions about saving, investment (stocks/bonds/life insurance products), work hours, and the benefit claiming age. We show that family status has enormous impact on investment and claiming decisions. Couples with children invest less in risky assets and purchase much more life insurance than childless couples or singles. Also married women claim their own Social Security benefits much earlier than single women, while married men claim much later. Interestingly, children have little impact on claiming decisions. These predictions from our theoretical model are consistent with empirical evidence in the Health and Retirement Study (HRS). We also show that Social Security benefits have a powerful impact on how households manage financial wealth and work 
patterns. Reducing survivor benefits would lead to higher life insurance demand on men, later claiming and more work hours for women, with little impact on allocations to risky stocks.

Our research builds on and extends the literature initiated by Merton (1969) on life cycle consumption and portfolio choice models. Recent researchers have sought to make these models more realistic by introducing new risk sources, ${ }^{2}$ important non-financial assets, ${ }^{3}$ and endogeneity of labor supply or retirement ages. ${ }^{4}$ While most life cycle asset allocation studies take the perspective of an individual representative agent rather than examining the possibly differing perspectives of households of varying sizes and compositions, Love's (2010) work is an important exception. His was the first model $^{5}$ to incorporate the effect of family and marital status risk on portfolio and saving choice, drawing on PSID data and the Urban Institute's Model of Income in the Near Term (MINT) to fit family transition probabilities, housing cost processes, and labor income that depend on age, sex, marital status, and children. His main results are that, first, children lead on average to less accumulation of financial assets while present in the household, but second, they also increase the household's share of risky assets. In addition, he showed that households with children have substantially higher demand for term life insurance than singles. Yet this important prior study is silent on the likely impact of endogenous labor supply and retirement age on optimal household patterns, taking account of Social Security rules. By contrast, our realistic formulation of Social Security benefit options departs rather dramatically from prior studies which assume that retirement benefits are simply a fixed fraction of labor earnings as of a pre-specified date. And our more general approach permits us to evaluate possible policy reforms such as changes in Social Security rules.

Other work related to ours includes that of Shoven and Slavov (2012) and Coile et al. (2002), who explore the payouts from various benefit claiming options under U.S. Social Security system rules. Gustman and Steinmeier (2005) analyze, using a structural estimation model, how retirement and claiming patterns respond to Social Security incentives. Yet these studies from the public finance literature focus only on the retirement phase of the life cycle, and hence they do not integrate the portfolio choice problem within a full household optimization framework. Hubener et al. (2013) develop a multi-person portfolio choice model

\footnotetext{
${ }^{2}$ For example, non-tradable risk labor income by Viceira (2001) and Cocco et al. (2005), interest rate risk by Campbell and Viceira (2001), health risk by French (2005), and risk on housing expenditures by Gomes and Michaelides (2005).

${ }^{3}$ For example, housing wealth by Cocco (2005), life annuities by Horneff et al. (2008) and Inkmann et al. (2011).

${ }^{4}$ See Bodie et al. (1992), Farhi and Panageas (2007), Gomes at al. (2008), and Chai et al. (2011).

${ }^{5}$ Earlier work by Scholz et al. (2006, 2007) explored the impact of children on wealth accumulations within a life cycle framework, but it assumed exogenous labor supply/retirement dates and excluded portfolio choice decisions.
} 
of a retired couple, allowing for investments in risky stocks, annuities, and life insurance purchases. Once again, however, that paper is silent on the work life issue and it adopts a simple Social Security benefit rule.

In what follows, we develop the structure of the life cycle portfolio choice model for households with uncertain family status, time budget constraints that depend on the arrival of children, and realistic Social Security benefit options. Section 3 presents the calibration of the parameters, most importantly the impact of the arrival of children on available time for work and the dynamics of uncertain wage rates. In section 4, we discuss the main findings from the model simulations and compare our model predictions about claiming with empirical evidence from HRS data. Section 5 explores possible policy reforms like changes in benefit structures under Social Security rules. A final section concludes and summarizes results.

\section{The Life Cycle Optimization Model}

In our model, agents face the risk of exogenous family transitions throughout their working lives and into retirement. In the following, $x(y)$ denotes a woman (man). Time $t=(0, \ldots, T)$ is measured in years. At time $t=0$ (assuming age 20 for women and 24 for men) the individual starts working life and can be either single or married. We assume that the four year age difference between spouses is fixed over the life cycle. Each individual has an uncertain life span and may live for a maximum of $T=80$ years.

\subsection{Family dynamics}

The state variable family $s_{t}$ is modeled at each point in time as a Markov chain with 35 discrete states. Before retirement, the possible family states are never married, married couple, divorced, and widowed. We further differentiate each of these states for the woman or the man. In addition, a household can have between zero and three children. We do not distinguish between never married, divorced, and widowed single retirees. Possible retirement states for couples include only the wife being retired, only the husband being retired, and both spouses being retired. For modeling spousal benefits, it is also necessary to differentiate these states with respect to the age when the husband claimed his own retirement benefits (see section 2.5). A complete list of all possible family states is given in Appendix A.

The time-dependent transition matrix $\Pi_{i j, t}=\operatorname{Prob}\left(s_{t}=i \mid s_{t+1}=j\right)$ for this Markov chain is influenced by five factors: mortality, marriage, divorce, fertility, and children leaving the household. We abstract from multiple births and divorces during retirement. We only allow married couples to receive children, and we treat three or more children as the 
same family state. ${ }^{6}$ In the case of a divorce, children are assumed to stay with their mothers. ${ }^{7}$ At the end of our projection horizon $T$, which corresponds to an age of 100 for women and 104 for men, we set the survival probability to zero. In the following, we describe the model for couples and refer to the single case only when it is not a straightforward simplification of ignoring the absent partner.

\subsection{Financial products}

Individuals may select from three different financial products to manage their liquid wealth: riskless bonds, risky stocks, and term life insurance. Bonds are characterized by a constant annual real gross rate of return $R_{0}$. The distribution of the stock return $R_{t}$ is assumed to be lognormal and serially independent.

In each period $t$, the individual $i \in\{x, y\}$ may purchase a one-year term life insurance contract. If the insured person dies within the period $[t, t+1]$, any surviving spouse or children receive the face value $L_{t}^{i}$ at time $t+1$. If the insured person survives, no payments are distributed, since no cash value is built up by the insurance contract. According to the actuarial principle of equivalence, the premium $L P_{t}^{i}$ charged by the insurance company equals the present value of the expected payout plus some expense loadings $\delta_{t}^{i}$, which is given by

$$
L P_{t}^{i}=\left(1+\delta_{t}^{i}\right) \cdot\left(1-p_{t}^{i}\right) \cdot \frac{L_{t}^{i}}{R_{0}} .
$$

Here $p_{t}^{i}$ denotes the probability from a mortality table that individual $i$ conditional on being alive at time $t$ survives to time $t+1$. The (age-dependent) loading factor $\delta_{t}^{i}$ reflects expenses covered by the insurance company for administration and to control for adverse selection. ${ }^{8}$

\subsection{Time budget}

Each individual has an available time budget $\Theta$. Depending on family status and age, a certain amount of time must be spent on child care $\theta_{s, t}^{i}$. Before retirement, the worker can decide how much of the available time he will spend in the paid labor market $\tau_{t}^{i}$ to generate labor income. Working for pay inflicts (unpaid) commuting time $\tau_{\mathrm{t} \text {, trav }}^{i}$ Time remaining is utility-increasing leisure $l_{t}^{i}$. Accordingly, the time budget equation is given as follows:

\footnotetext{
${ }^{6}$ This limits computational effort. Moreover, the marginal effects of an additional child regarding consumption scaling or child care time decrease with the number of children.

${ }^{7}$ The different number of children for a divorced husband matters only for child support payments and affects the possible family states to which he may switch.

${ }^{8}$ Modeling life insurance as multi-year contracts would require at least one more state variable for each additional spouse, which would make the model intractable. See Hubener et al. (2013) for a discussion of how single period life insurance contracts can substitute for longer-running contracts.
} 


$$
\Theta=\theta_{s, t}^{i}+\tau_{t}^{i}+\tau_{t, \text { trav }}^{i}+l_{t}^{i}
$$

\subsection{Labor income}

Depending on the time devoted to paid work $\tau_{t}^{i}$, each agent earns uncertain labor income specified as follows:

$$
Y_{t}^{i}=\tau_{t}^{i} \cdot w_{s, t}^{i} \cdot P_{t} \cdot \varepsilon_{t}
$$

Here $w_{s, t}^{i}$ denotes the wage rate which depends on sex, age, and family status. The variable $\varepsilon_{t}$ is an independent identically lognormal distributed transitory income shock with mean of one, and $P_{t}$ is the permanent component of the wage rate with lognormal shock $\eta_{t}$ evolving according to:

$$
P_{t+1}=P_{t} \cdot \eta_{t}
$$

Note that, in the case of a couple, the transitory shock as well as the permanent income component is assumed to affect both spouses identically or, equivalently, both transitory and permanent shocks are perfectly correlated across partners. ${ }^{9}$ The permanent income component $P_{t}$ (and its shock $\eta_{t}$ ) have a mean of one, such that $w_{s, t}^{i}$ is the average wage for the given combination of sex, age, and family state.

\subsection{Retirement income}

From age 62 onward, each spouse has the possibility of claiming Social Security retirement benefits, up to age 70 when claiming becomes mandatory. The retirement income payable to the individual is equal to his Primary Insurance Amount (PIA), which is based on lifetime earnings with adjustment for early or delayed benefit claiming. The Social Security retirement benefit is given by:

$$
Y_{t}^{i, r e t}=P I A_{t}^{i} \cdot \lambda^{i} \cdot \varepsilon_{t}^{r e t}
$$

with $\lambda^{i}$ being the adjustment factor for early claiming reduction or delayed retirement credit (relative to the Full Retirement Age), and $\varepsilon_{t}^{\text {ret }}$ is a lognormal transitory shock with a mean of one.

In accordance with U.S. practice, the PIA is based on the earnings history. Using a concave piece-wise linear function, the PIA is computed from the Average Indexed Monthly Earnings (AIME), which is the worker's average monthly labor earnings over his (wage-

\footnotetext{
${ }^{9}$ The modeling of different income shocks requires one additional state variable which increases the computational burden of solving the model.
} 
appreciation adjusted) best 35 years. To keep the model tractable, we use the PIAs for each spouse as state variables. To be precise, the state variable after claiming is the benefit amount, which is the product PI $A_{t}^{i} \cdot \lambda^{i}$ of the PIA and the adjustment factor for early claiming reduction or delayed retirement credit. Hence we need not treat the claiming age as a different state variable. ${ }^{10}$ Further details on how the PIAs are used as state variables can be found in Appendix C.

After claiming retirement benefits, individuals still have the opportunity to continue working until age 70 . If they do, they are taxed at a rate of 50 cents per dollar earned above the exempt amount of the retirement earnings test, consistent with the U.S. Social Security rules. $^{11}$

After both partners have claimed their retirement benefits, the partner with the lower retirement income may elect to receive spousal benefits instead of his own benefits. These amount to $50 \%$ of the partner's benefits, unless the spousal benefits are claimed before reaching Full Retirement Age. In this case, a permanent reduction of up to 30\% applies. In contrast to own retirement benefits, claiming spousal benefits after the Full Retirement Age is not incentivized with an increase of lifelong payments. Since tracking the claiming age for spousal benefits requires an additional state variable, our model framework only allows for claiming spousal benefits at the Full Retirement Age. ${ }^{12}$ After this age, a partner receives spousal benefits, if these exceed the own already-claimed old age retirement benefits. Another rule is that if one partner claims after his Full Retirement Age, the delayed retirement credit only increases his own benefits, but not his partner's spousal benefits. In order to exclude the delayed retirement credit for spousal benefits, we use separate retirement states for different claiming ages of the husband. ${ }^{13}$

When a spouse passes away, the surviving spouse may switch to widow(er) benefits. These are equal to $100 \%$ of the deceased spouse's benefits. In our model, this is not an active decision; instead, these benefits are automatically paid if the widow(er) benefits are higher. If retirement benefits have not yet been claimed, the PIA of the surviving spouse is substituted in place of the PIA of the deceased spouse. Accordingly, we need not keep track of whether the widow(er)'s PIA results from own work history or that of a deceased spouse.

\footnotetext{
${ }^{10}$ For a couple, there are 81 possible combinations.

${ }^{11}$ Survey evidence shows that most people do understand Social Security benefits are reduced by the earnings test, but most are unaware that their benefits foregone are paid back after the Full Retirement Age; see Brown et al. (2013). Nevertheless, this has been true only since the year 2000.

${ }^{12}$ If the spousal benefits exceed the wife's own benefits at the Full Retirement Age, but she would like to receive benefits from age 62 onwards, she can claim her own benefits at this age, and switch to her spousal benefits four years later. In this way, she can avoid a permanent benefit reduction.

${ }^{13}$ Our results suggest that this differentiation is only necessary for husbands, since their retirement benefits are never less than half their wives' benefits.
} 
This quite realistic formulation of Social Security benefit options differs from and extends substantially the typical approach taken in prior portfolio choice life cycle studies. That is, the usual approach until now has been to assume that the worker's retirement benefit is given by a fixed proportion of his last labor income as of a prespecified date. ${ }^{14}$ Moreover, prior studies have not modeled spousal or survivor payments, ignoring the possibility that one spouse could claim first on her own account, and later switch to alternative benefit payment options.

\subsection{Wealth dynamics}

Besides determining how much time to spend working, each period the household must also decide how much of its liquid wealth $\left(W_{t}\right)$ to spend on consumption $\left(C_{t}\right)$, life insurance premiums for $\left(L P_{t}^{x}, L P_{t}^{y}\right)$ for the wife (husband) $\mathrm{x}(\mathrm{y})$, and how to allocate savings to bonds $B_{t}$ and stocks $S_{t}$. The household is liquidity constrained, so that it cannot borrow to finance consumption and life insurance purchases:

$$
\begin{aligned}
& \mathrm{W}_{\mathrm{t}}=\mathrm{C}_{\mathrm{t}}+\mathrm{LP}_{\mathrm{t}}^{\mathrm{x}}+\mathrm{LP}_{\mathrm{t}}^{\mathrm{y}}+\mathrm{B}_{\mathrm{t}}+\mathrm{S}_{\mathrm{t}} \\
& \mathrm{LP}_{\mathrm{t}}^{\mathrm{x}} \geq 0 \quad \mathrm{LP}_{\mathrm{t}}^{\mathrm{y}} \geq 0 \quad \mathrm{~S}_{\mathrm{t}} \geq 0 \quad \mathrm{~B}_{\mathrm{t}} \geq 0
\end{aligned}
$$

Next period's liquid wealth is given by any remaining wealth including capital market returns, labor income $\left(Y_{t}^{i}\right)$, and Social Security benefits $\left(Y_{t}^{i, \text { ret }}\right)$, less income taxes according to proportional rates $\vartheta_{\text {labor }}$ and $\vartheta_{\text {ret }}$ and housing expenses $h_{s, t}$ :

$$
\begin{aligned}
W_{t+1}= & S_{t} \cdot R_{t+1}+B_{t} \cdot R_{0}+\left(1-\mathbb{I}_{t+1}^{x}\right) L_{t}^{x}+\left(1-\mathbb{I}_{t+1}^{y}\right) L_{t}^{y} \\
& +\left(\left(Y_{t}^{x}+Y_{t}^{y}\right) \cdot\left(1-\vartheta_{\text {labor }}\right)+\left(Y_{t}^{x, \text { ret }}+Y_{t}^{y, \text { ret }}\right) \cdot\left(1-\vartheta_{\text {ret }}\right)\right) \cdot\left(1-h_{s, t}\right)
\end{aligned}
$$

The indicator variables $\mathbb{I}_{t}^{x}$ and $\mathbb{I}_{t}^{y}$ are equal to one if the corresponding spouse is alive at time $t$ and zero otherwise. Other cash flows might occur due to family state transitions. If one of the spouses $i$ dies, the remaining spouse $j$ receives the payment from the life insurance contract $L_{t}^{i}$. If one child leaves the household, we assume the parents must pay college fees (here designed as a lump sum). Furthermore, a divorced woman with children receives child support payments, while a divorced husband with children must devote a certain fraction of his income for child support.

\footnotetext{
${ }^{14}$ See for instance Cocco et al. (2005) and Love (2010). Chai et al. (2011) do incorporate a flexible retirement age and a delayed retirement credit, but their study does not track lifetime earnings. Also it takes the perspective of a single representative worker instead of a multi-person household with uncertain family status, as here.
} 


\subsection{Preferences and optimization}

We impose that the household has a time-additive utility function with constant relative risk aversion $\gamma$, and it derives utility from a composite good consisting of consumption $C_{t}$ and effective leisure $l_{t}$. Depending on the number of adults and children present in the household, total consumption is normalized by a scaling factor $\phi_{s}$ (see Love, 2010 and Hubener et al., 2013). For a single adult, effective leisure is identical to time devoted to leisure, whereas for a couple, effective leisure is given by the geometric mean of both spouses’ leisure times: ${ }^{15}$

$$
l_{t}=\sqrt{l_{t}^{x} \cdot l_{t}^{y}}
$$

The relative importance between consumption and leisure is given by a modified Cobb-Douglas function, whereby the preferences for leisure are governed by the parameter $\alpha$. The household's expected lifetime utility can be expressed by the recursive Bellman equation

$$
\begin{aligned}
J_{t}\left(W_{t}, P_{t}, P I A_{t}^{x}\right. & \left.P I A_{t}^{y}, s_{t}\right) \\
& ={ }_{C_{t}, \tau_{t}^{x}, \tau_{t}^{y}, S_{t}, B_{t}, L P_{t}^{x}, L P_{t}^{y}}\left\{\frac{1}{1-\gamma}\left(\frac{C_{t}}{\phi_{s}} \cdot l_{t}^{\alpha}\right)^{1-\gamma}\right. \\
& \left.+\beta E_{t}\left[J_{t+1}\left(W_{t+1}, P_{t+1}, P I A_{t+1}^{x}, P I A_{t+1}^{y}, s_{t+1}\right)\right]\right\},
\end{aligned}
$$

where $\beta$ represents the time preference rate. The value function is governed by the state variables financial wealth $W_{t}$, the permanent income component $P_{t}, P I A_{t}^{x}$ and $P I A_{t}^{y}$, and the family state $s_{t}$. The controls are consumption $C_{t}$, working time $\tau_{t}$, investments in stocks $S_{t}$ or bonds $B_{t}$, and premiums for life insurance purchases $L P_{t}^{x}$ and $L P_{t}^{y}$.

The expectation of the household's future value function is the sum over all possible family states weighted using the transition probability $\Pi_{s_{t}, s_{t+1}}$.

$$
E_{t}\left[J_{t+1}\left(W_{t+1}, A_{t+1}, s_{t+1}\right)\right]=\sum_{s} \Pi_{s_{t}, s} E_{t}\left[J_{t+1}\left(W_{t+1}, A_{t+1}, s_{t+1}=s\right)\right]
$$

An exception is the case of divorce, the only instance in which a household is split into two separate units, each with a different utility function. In this case, the individual value functions are equally weighted:

\footnotetext{
${ }^{15}$ Just as total consumption of the couple is normalized to the individual level using a scaling factor, Formula (9) scales both spouses' total leisure time to an individual level. Instead of taking an arithmetic mean, by using the geometric mean we ensure a finite elasticity of substitution between the leisure times of both partners. This avoids corner solutions (i.e., only partner works without having own leisure time) and ensures that partners seek to balance their individual time devoted to leisure.
} 


$$
E_{t}\left[J_{t+1}\right]=\frac{1}{2} E_{t}\left[J_{t+1}\left(s_{t+1}=\text { divorced woman }\right)\right]+\frac{1}{2} E_{t}\left[J_{t+1}\left(s_{t+1}=\text { divorced man }\right)\right]
$$

If one spouse dies, the desire to provide for the surviving partner is reflected in the corresponding value function of the surviving spouse. If the last or both spouses die, they may wish to provide for their children or leave a bequest. The strength of this bequest motive is given by the parameter $B_{s, t}$. The corresponding utility is given by remaining wealth normalized by the bequest parameter and multiplied by the available time budget: ${ }^{16}$

$$
\left.\begin{array}{cc}
J_{t}=\frac{1}{1-\gamma}\left(\frac{W_{t}}{b_{s, t}} \cdot \Theta^{\alpha}\right)^{1-\gamma} & \text { for } b_{s, t}>0 \\
J_{t}=0 & \text { for } b_{s, t}=0
\end{array}\right\} \text { if both spouses have died }
$$

Between ages 62 and 69, each spouse has the opportunity to claim his Social Security benefits. At age 70, no further delayed retirement credit can be earned and claiming is mandatory. Table A1 in Appendix A lists the possible retirement states to which transitions by claiming benefits are possible. If the utility of a retirement state exceeds the utility of the current state calculated from equation (10), the utility of the current state is replaced by the higher value and the couple switches to the retirement state. ${ }^{17}$

\section{Model Calibration and Parameterization}

\subsection{Family process calibration}

The drivers of family state transitions are marriage hazards, divorce hazards, fertility, children leaving the household, and mortality. We calibrate our probabilities for marriages and divorces using the Urban Institute's Model of Income in the Near Term, Version 6 (Smith et al., 2010). In this model, current age and sex is related to marriage and divorce hazard rates, the number of previous marriages, and the duration of the current marriage time since last marriage. To parameterize the transition probability matrix, we simulate a population of $1,000,000$ people with an initial marriage rate of $20 \%,{ }^{18}$ for which we track the number and duration of marriages. These then evolve according to the MINT hazard rates. We derive the transition probability $\Pi_{i j, t}$ by dividing the number of transitions in our simulated population

\footnotetext{
${ }^{16}$ The multiplication with some leisure is necessary for the bequest utility being measured in the same units as the utility from consumption and leisure. To use the time budget $\Theta$ is equivalent to normalizing $\Theta=1$ and using $J_{t}=\frac{1}{1-\gamma}\left(\frac{W_{t}}{B_{s, t}}\right)^{1-\gamma}$ as utility from bequest.

${ }^{17}$ If there are several retirement states to which the couple could switch, the state with the highest utility is chosen.

${ }^{18}$ A marriage rate of $20 \%$ for 20 year old women and 24 year old men is in line with the MINT study and a bit higher than the National Health Statistics Report (Copen et al., 2012), which reports a marriage rate of 17.3\% for women and $11.3 \%$ for men age $20-24$. But if we add the cohabitation rates (most comparable to the married couple family state) of $18.7 \%$ and $15.0 \%$, our assumption is on the low side.
} 
from state $i$ to state $j$ at age $t$ by the number of paths in state $i$. In the MINT model the number of children does not affect hazard rates, so these transitions are independent of the number of children. Fertility-driven transitions probabilities are determined in a subsequent step.

For the transitions between family states with different numbers of children, we use 2009 values of the all race fertility rates from the National Vital Statistics Reports (Martin et al., 2011). Reported fertility rates are adjusted for the fact that in our model, only married couples have children. ${ }^{19}$

We assume that children leave the household when they turn age 18. Since our state variables track only the numbers of children but not their age, we again simulate a population with the already-calibrated fertility, marriage, and divorce transitions, and we track the ages of the children and make them leave the household after 18 years. The transition probability to states with one fewer child $\Pi_{i j, t}$ is given by the number of paths at age $t$ with a child turning 18 in state $i$, divided by the total number of paths in state $i$.

Mortality transitions to widow or widower states are given by sex and age-dependent one-year survival probabilities, for which we use the U.S. 2001 population life table in the National Vital Statistics Report 2005 (Arias, 2010).We assume survival probabilities are independent of family status.

\subsection{Time budget and child care time}

Each spouse is assumed to have a time budget of $\Theta=16$ hours per day, and the possible work week consists of five days (relevant for distinguishing between full, part time, and over-time work). We further assume a year to have 52 weeks (relevant for transformation to annual values) and a month being $1 / 12$ of a year (relevant for determining the AIME and PIA).

To calibrate state and age dependent child care time $\theta_{s, t}^{i}$ we use data from 2003-2011 waves of the American Time Use Survey. ${ }^{20}$ The U.S. Census Bureau conducts the ATUS as an extension to the Current Population Survey (CPS). Two to five months after households complete the last CPS interview, they are eligible for the ATUS. One adult per household is randomly selected to do the interview; this structure precludes us from analyzing empirically the interaction of couples' time allocations. The 24-hour time diaries are collected using

\footnotetext{
${ }^{19}$ The National Vital Statistics Reports give the fertility rate of the complete population $f_{\text {tot }}$, the fertility rate of unmarried women $f_{u}$, and the fraction $r$ of unmarried births to all births. The fertility of married women is then derived by: $f_{m}=\frac{1-r}{\frac{1}{f_{\text {tot }}}-\frac{r}{f u}}$

${ }^{20}$ A good description of the ATUS can be found in Hamermesh et al. (2005)
} 
telephone interviews, when the respondents report each activity of the previous day and its corresponding duration. The interviewer assigns each reported activity a code categorized into 17 top-level categories with several sub-categories. After the first wave of 2003 with 20,720 respondents, there were about 13,000 respondents in each subsequent wave. ${ }^{21}$

In the prior life cycle literature with endogenous labor supply (Gomes et al., 2008; Chai et al., 2011), time is only divided into (income generating) working time and leisure. In this sense, leisure cannot be seen exclusively as recreational, since it incorporates both pure leisure and home production (Gronau, 1977). Similar to children's effects on consumption, represented in our model by a consumption scaling factor $\phi_{s}$, child care time $\theta_{s, t}^{i}$ is intended to capture the effect of children on the parents' time budgets. But considering only time directly devoted to children would underestimate the truth, since other activities may take longer with children present in the household (for example, cleaning the house or cooking for more people). In this sense $\theta_{s, t}^{i}$ cannot be viewed as child care only, but rather it is the marginal effect of children on all activities related to home production.

Accordingly, for the calibration of $\theta_{s, t}^{i}$, we consider the following ATUS activities as home production time: Caring For \& Helping Household Members ${ }^{22}$, Household Activities, Consumer Purchases, Caring For \& Helping Nonhousehold Members, Professional \& Personal Care Services, ${ }^{23}$ Household Services, Government Services \& Civic Service, and all travel related to those activities. ${ }^{24}$

We divide the ATUS respondent sample into four subgroups: married women, married men, single women, and single men, and we drop observations older than age 66. Next, we include only those observations where the age difference to the youngest child is at least 18 years and at most 45 (55) years for women (men). ${ }^{25}$ Finally, we exclude the time diaries filled out on holidays or weekends. Naturally, we include observations with and without children to identify the effect of children. We regress the time spent on the aforementioned activities on a set of dummies for the number of children (with one dummy representing three or more

\footnotetext{
${ }^{21}$ Slightly more than half the diaries are recorded on the weekend or a holiday.

${ }^{22}$ This includes all 19 activities related to children like physical care, supervising children's activities, and playing with them. Even though the latter can be seen as recreational leisure, we choose not to exclude it due to its direct reference to the effect of children on available time.

${ }^{23}$ Note that these are the time costs to make use of the service, as for example waiting on a baby sitter.

${ }^{24}$ We exclude the following activities: Personal Care, Work \& Work-Related Activities, Education, Eating \& Drinking (without food preparation), Socializing, Relaxing, \& Leisure, Sports, Exercise, \& Recreation, Religious \& Spiritual Activities, and Volunteer Activities. Our model assumes a day has 16 waking hours and hence we exclude personal care, which is mainly sleeping time besides washing, dressing, and grooming. Education is excluded due to its close relation to work and all the other activities are recreational leisure.

${ }^{25}$ There is no indicator as to whether the children in the home are the biological children or not. These restrictions should minimize the observations of people looking after their underage siblings and grandparents looking after their grandchildren.
} 
children), and a second/third ${ }^{26}$ order polynomial in the number of years until the youngest child turns age 18. The results of the OLS regression appear in Table 1, with a graphical representation in Figure 1. In general, women allocate more time than men to home production; for them, children also cause a higher time increase in non-market activities, compared to men. Single women do spend less time on these activities than married women, but the effect of (at least the first two) children is about the same for both female groups.

Table 1 and Figure 1 here.

For someone with no children, the set of child dummies and the age of the youngest child are set to zero, so the regression constant term reflects time spent on home production when no children are present. As mentioned above, $\theta_{s, t}^{i}$ captures only the marginal effect of children on home production time, so rather than setting $\theta_{s, t}^{i}$ to the estimated home production time for each family state $s$, we set $\theta_{s, t}^{i}$ to the difference in home production time with reference to someone having a similar marital status but with no children (e.g., married couple with two children versus a married couple with no children).

As already discussed, our state variables do not directly track the ages of children at home. Instead, for the calibration of transition probabilities, we simulate a population keeping track of the children's ages. For each path, child care time is calculated according to the regression results, ${ }^{27}$ and the value $\theta_{s, t}^{i}$ is derived by computing the mean over all paths for corresponding family state $s$ at (parent's) age $t$.

We also use the ATUS for calibrating the time needed to commute to work. The sample mean for those who worked at least an hour for pay and travelled to work less than four hours on the diary day is $\tau_{\mathrm{t} \text {, trav }}^{x}=0.64$ hours for women and $\tau_{\mathrm{t} \text {, trav }}^{y}=0.79$ hours for men.

\subsection{Wage rate calibration}

We estimate the deterministic component of the wage rate process $w_{s, t}^{i}$ and the variances of the permanent and transitory wage shocks $\eta_{t}$ and $\varepsilon_{t}$ using the 1995-2009 waves of the Panel Study of Income Dynamics. Besides age, sex, and education, we are especially interested in the effect of the family status and work hours on the hourly wage. In the data set, some respondents directly report a wage in terms of dollars per hour; for the remainder of the observations, we infer the hourly wage by dividing annual income by annual work hours.

\footnotetext{
${ }^{26}$ For all other subgroups except married women, the coefficient of third order in child age is not significantly different from zero, so we reduced the order of the polynomial for them.

${ }^{27}$ Since the number of single men with children is small, we use the regression results of single women for widowed men with children.
} 
Annual work hours are given by the hours worked per week ${ }^{28}$ multiplied by 52 . All dollar values are in $\$ 2009$.

For the explanatory variables in the wage rate equation, we use a polynomial up to second order in the respondent's age, a vector of dummy variables for the number of children under 18 in the household and whether a spouse is present in the household, and a set of dummies representing work: full time for pay (between 20 and 40 hours per week), part time (more than zero but less than 20 hours per week), or overtime (over 40 hours per week).

For couple households, we treat each spouse as a different observation. By using wage or inferred wage as the dependent variable, we automatically limit the sample to the working population for which we can infer this quantity. We also eliminate all observations with hourly wage rates of below \$5 (which contradicts minimum wage laws) and extreme observations above the $99^{\text {th }}$ percentile. Furthermore, we divide the sample according to sex and education into four subgroups: men with a high school education, women with a high school education, men with a college education, and women with a college education.

Table 2 shows the results of an OLS regression of the natural logarithm of hourly wages. ${ }^{29}$ In Figure 2, the age dependence is presented for the four subgroups who work full time and have a spouse but no children. For both education groups, men have higher wages than women ${ }^{30}$ and the gap widens with age. For all subgroups, living together with a spouse increases the wage significantly, by over $10 \%$. Having children slightly increases men's wages (significant only for those with a college education), while it significantly decreases women's wages by about $5 \%$ for two and $10 \%$ and more for three or more children. There are large wage reductions for part-time work (up to 20\%), and the reductions are twice as large for men as for women. Working overtime yields higher wage rates for all four groups, with the largest bonus for the high school educated.

Table 2 and Figure 2 here

For estimating the variances $\sigma_{\eta}^{2}$ and $\sigma_{\varepsilon}^{2}$ of shocks $\eta_{t}$ to permanent income and $\varepsilon_{t}$, to transitory income, we follow the well-established procedure of Carroll and Samwick (1997). The idea is that the residual of the observed log wage in the PSID and the predicted log wage from our regression results can be attributed to permanent income and transitory shocks $\ln P_{t}+\ln \varepsilon_{t}$. Let $r_{i, d}=\left(\ln P_{t+d}+\ln \varepsilon_{t+d}\right)-\left(\ln P_{t}+\ln \varepsilon_{t}\right)$ be the difference of these residuals of waves being $d$ years apart for individual $i$. Under the assumption of serially

\footnotetext{
${ }^{28}$ For waves 95-07, hours worked in the individual's Main Job were reported; in wave 09, only hours worked in All Jobs were reported so Main Job could not be inferred. Yet there is no significant difference in the sample mean and standard deviation of hours worked, or the wage regressions, if the 09 wave is omitted.

${ }^{29}$ Dummies for each wave are also included as explanatory variables (results available on request).

${ }^{30}$ There is an exception for college education, where women earn more between ages 20-26.
} 
uncorrelated and independent shocks, this difference has a variance of $\sigma_{\eta}^{2}+2 \sigma_{\varepsilon}^{2}$. Regressing the squared differences $r_{i, d}^{2}$ on the time span $d$ between waves and a constant vector of 2's yields an estimate for these variances.

The results of our calibration appear at the bottom of Table 2. Since we assume identical shocks for both spouses, we split the sample only by education but not by sex. Compared to Love (2010) who based his empirical analysis on a broader definition of household income (including public transfers and unemployment compensation, as well as labor income), our estimate of the variance of permanent shocks $\sigma_{\eta}^{2}$ is lower for the less educated and about the same for the college educated. Our variance of transitory shocks $\sigma_{\varepsilon}^{2}$ is considerably lower for both educational groups. The broader definition of household income used by Love (2010) versus ours (wage rates) might be more prone to fluctuations. The effect of unemployment in particular is not incorporated in our model or regressions, since we cannot infer wage rates when individuals are unemployed.

For retirement income, which is purely a public transfer in our model, these conceptual differences no longer apply. Therefore, for the variance of transitory shocks to retirement income we set $\sigma_{\varepsilon^{r e t}}^{2}=0.0784$ from Love (2010).

\subsection{Other parameters}

Emulating several other studies in the life cycle literature, we use the consumption scaling factor $\phi_{s}=(A+0.7 \cdot K)^{0.7}$ proposed by Citro and Michael (1995), with $A$ being the number of adults and $K$ being the number of children in the household. Our calibration of bequest strength $b_{s, t}$ is motivated more by the provisional motive (i.e., spousal protection) than a pure bequest motive to cover children (Hubener et al., 2013). We set $b_{s, t}$ to zero for any family states without children present in the household. Otherwise, we assume that an annuity must be purchased that finances the consumption for each left-behind child until his $18^{\text {th }}$ birthday, plus four more years for college. ${ }^{31}$ As the age of children is not explicitly tracked in our model, we again use the same simulation technique as before for the family transition probabilities and child care time estimation to derive mean values of $b_{s, t}$ for family state $s$ at each age $t$.

We choose a relative risk aversion of $\gamma=5$ and set the time discount factor to $\beta=0.96$. The leisure preference parameter is given by $\alpha=0.8$, since for this value, the

\footnotetext{
${ }^{31}$ Abstracting from discounting with the riskless rate, a 15- and a 17 -year old child yield bequest factors of $b=5 \cdot(0.7 \cdot 2)^{0.7}+2 \cdot(0.7 \cdot 1)^{0.7}=7.89$, since consumption must be financed for five years for both children and another two years for the youngest child.
} 
optimal life cycle profiles for hours worked per week roughly match the average work hours in the PSID data used for the calibration of the wage rate (also see Appendix B).

The risk-free rate is set to $R_{0}=1.02$, and we assume an equity premium for stock returns of $E\left[R_{\mathrm{t}}\right]-R_{0}=4 \%$. The standard deviation of stocks returns is $20 \%$. Life insurance contracts are priced according to the 2001 Commissioners Standard Ordinary (CSO) Mortality Table, which was developed by the Society of Actuaries and the American Academy of Actuaries (2002). As in Gomes et al. (2008), labor earnings are taxed at a rate of $\vartheta_{\text {labor }}=30 \%$ and retirement benefits at $\vartheta_{\text {ret }}=15 \%$.

Several other parameters are calibrated following Love (2010): for instance, we use his estimation of housing costs $h_{s, t}$ from PSID data; for child support, divorced men are assumed to pay $17 \% / 25 \% / 30 \%$ of their labor income for $1 / 2 / 3+$ dependent children; divorced women with children receive the corresponding fraction of a single man's income as if he works for 40 hours per week; if a child turns age 18, the household pays $40 \%$ of its income for college costs $^{32}$ upon his departure; in the case of divorce, wealth is split evenly between spouses after deducting $10 \%$ of assets for divorce costs.

When a single individual marries, we must make some assumptions about the new partner. First, we posit that the new partner has the same permanent wage rate component $P_{t}$ as the single individual had before. Second, the PIA of the new husband is an age-dependent multiple of the wife's PIA ranging between 1.04 in their early 20's and 1.13 just before retirement. Third, the financial wealth brought by the husband into the couple's wealth is also an age-dependent multiple of the wife's wealth ranging between 1.06 early and 1.19 late in life. $^{33}$

When a couple divorces, the partner with lower retirement benefit claims is entitled to spousal benefits, and after the former partner's death, to widow(er) benefits. Our model does not track the PIA of former partners, so we increase the PIA of a divorced woman (man) to 70.85\% (58.23\%) of the former partner if her (his) own PIA is smaller. This is motivated by the following consideration: an annuity paying $\$ 50$ per year to a woman as soon as her former husband reaches full retirement age, and \$100 after his death, as long as the woman lives, has the same actuarially fair present value as an annuity paying the woman $\$ 70.85$ per year

\footnotetext{
${ }^{32}$ Based on a study by Turley and Desmond (2006), Love assumes college costs of $10 \%$ of the family's income for four years. Since the family states in our model do not contain any information on the number or even the ages of children already having left the household, we have to model this payment as a lump sum upon the child's leaving.

${ }^{33}$ We derive these multiples by assuming that both partners have worked full time up to this age. The ratio of the PIAs resulting from this work history yields the first multiple. Similarly, the second multiple is calculated from the ratio of corresponding average lifetime income.
} 
(because of the age difference and the asymmetry in the mortality rates, the corresponding value for men is only $\$ 58.23$ ).

For the piecewise linear function converting the AIME into the PIA, we use the official specification for the Social Security bend points. For the first $\$ 744$ of the AIME, 90 cents per dollar are transferred into the PIA, for values over this and up to $\$ 4,483$, 32 cents per dollar are transferred and for every additional dollar earned, on average, the PIA increases by 15 cents (in 2009 dollars). We set the exempt amount of annual income for the Retirement Earnings test to $\$ 14,160 .^{34}$ The deduction (bonus) for claiming early (late) old age retirement benefit is calculated according to Social Security claiming rules. As of the Full Retirement Age, defined here as age 66, retirement benefits as a fraction of the PIA are given by Table 3. Table 3 here

\section{Optimal Decisions on Saving, Work, Claiming, Life Insurance, and Investments}

In this section, we first analyze the household's optimal behavior over the life cycle. In particular, we are interested in how family status affects financial decisions (stocks, bonds, life insurance demand), work effort, and the optimal time to exercise the Social Security claiming option. Next, we discuss details on the simulation method of our life cycle model with changing family status. In Section 4.2, we present patterns of average consumption, wealth, holdings in stocks, work hours, and Social Security claiming ages. We discuss these patterns for women and men in a single or couple household. Further analysis on how education and the number of children influence optimal decisions is presented in Section 4.3. Finally, we investigate whether the predictions on claiming patterns from our model are consistent with empirical HRS data.

\subsection{Simulations}

We use the optimal controls of the baseline parameterization of our life cycle model to generate 100,000 simulated life cycles reflecting realizations of stock returns, wage rates, and marital status. We assume that $59.3 \%$ (40.7\%) of the simulated households have a wage rate profile corresponding to high school (college) education, which represents the distribution of educational status in the 2009 wave of the PSID. We divide the sample of simulated life cycles equally into female and male paths. At the start of the simulations, $80 \%$ are singles and

\footnotetext{
34 For additional information on Social Security benefit rules, see Myers (1985) and http://www.socialsecurity.gov/OACT/COLA/rtea.html.
} 
$20 \%$ are already married, while later in life each individual randomly moves between the 35 family states. Each household is endowed with a starting financial wealth as if each household member would have worked 40 hours per week in the previous period. We present the results in the usual way as in the life cycle literature, so we generate simulated paths conditional on survival. To do so, we modify the transition matrix $\Pi_{i j, t}$ for the simulation by setting the mortality of women in female paths and men in male paths to zero ${ }^{35}$ and rescale the other probabilities such that they sum up to 1 . This procedure keeps the same number of paths even at high ages. If a single agent marries, we make the same assumptions about the new spouse as in the optimization regarding age difference, permanent income, wealth, and PIA. In the case of divorce, we follow only the ex-wife (ex-husband) in a female (male) path and ignore the other spouse.

For the reporting of aggregate quantities over all paths, as for example, average wealth, each path is weighted with the survival probability up to the considered age. This gives female paths a slightly higher weight in comparison to male paths, especially at advanced ages. When sex dependent quantities like hours worked by women (men) are considered, we only report the average over female (male) paths.

We also report results for subsamples, e.g. single or couple households. In this case, we use averages over all paths in that family state at the reported age. Thus the samples are not constant at all different ages. For example, an individual being a single woman at one age drops out of the sample of single households for later ages, when she marries. This agent may reenter the subsample at a higher age, if a divorce occurs. Table 4 provides some basic information about the average composition of the simulated population dynamic at different ages.

Table 4 here

\subsection{Optimal life cycle profiles}

Figure 3 reports the average life cycle profiles for the complete population of singles and couples with either a high school or a college education. Panel A shows average consumption, life insurance demand, wealth level, and investments in equities. Panel B reports average work hours for men and women, and Panel $\mathrm{C}$ the frequency of claiming Social Security benefits. Here we see that financial wealth builds up gradually until age 55 when it amounts to about $\$ 160,000$ on average, and thereafter people start to draw down these

\footnotetext{
${ }^{35}$ However, the optimal decisions of the agents take mortality into account. The mortality of the spouses in couple states is not zero and states of widowhood are thus possible in the simulation.
} 
assets. The average wealth profile generated from our life cycle model is reasonably consistent with empirical data. For example, in the PSID (see Appendix B), the average financial wealth of households between age 25 and 75 is about \$136,000 (in \$’09), while households in our model have an average wealth of $\$ 134,000$ in this age bracket. But in our model the wealth profile is shaped slightly differently, as younger households have higher and older households have lower wealth in comparison to their empirical counterparts.

Figure 3 here

The level of financial wealth and the amounts individuals invest in risky stocks is highly correlated. Compared to other papers in the life cycle literature, ${ }^{36}$ our model generates a relatively low and stable fraction invested in the stock market. In the first decade of the life cycle, stock allocation rises from about $20 \%$ at age 20 , to $57 \%$ at age 35 . Subsequently the average allocation to stocks is quite stable, in a range of $41 \%$ to $57 \%$. After age 62 , when households start to claim Social Security benefits and receive their riskless benefits, the fraction invested in stocks slightly increases, to 54\%. There are two reasons for these low equity exposures. First, as noted by Love (2010), adding family status uncertainty (on top of permanent/transitory income and mortality shocks), forces households to select safer bond investments. Second, the portion of cash-on-hand dedicated to this period's consumption is assumed to be held in non-risky assets. ${ }^{37}$ The portfolio allocation generated by our life cycle model fits the empirical data quite well. For instance, several studies on U.S. household portfolio allocations report a relatively constant, non-decreasing equity share by age conditional on participation, of around $40 \%$ to $60 \%{ }^{38}$

Results also show that the average level of consumption increases over the work life. But consumption drops sharply around age 66, when many households retire and begin to consume more leisure. Such a profile is consistent with other life cycle models with endogenous work hours and flexible retirement age (Chai et al., 2011); ${ }^{39}$ it is also in line with empirical studies documenting a substantial drop in spending around the retirement date. For instance Bernheim et al. (2001) and Aguiar and Hurst (2005) report a drop of consumption after retirement for U.S. households of between 35 to 38 percent, depending on wealth levels. Figure 1B shows that men start off with an average of 44 work hours per week which they

\footnotetext{
${ }^{36}$ See Cocco et al. (2005), Gomes and Michaelides (2005), Gomes et al. (2008). Love (2010), or Chai et al. (2011).

${ }^{37}$ This is in line with recent work by Abel et al. (2013). Drawing on early work by Baumol (1952), that study uses a dynamic consumption and portfolio choice model where a liquid riskless asset held in a special transaction account is needed to cover consumption expenditures until the next period.

${ }^{38}$ See, for example, Guiso et al. (2002), Ameriks and Zeldes (2004), Gomes and Michaelides (2005), Love (2010), and Wachter and Yogo (2010).

${ }^{39}$ By contrast, life cycle models with exogenous labor income and retirement age, such as Cocco et al. (2005) and Love (2010), generate a quite smooth average consumption profile before and after working life.
} 
gradually reduce to around 40 hours right before the earliest possible retirement age. Women also work for pay more than 40 hours a week to their early 20's but reduce this to about 32 hours per week in their late 30’s. Thereafter, they increase paid work to 35 hours per week in their 50’s.

Compared to empirical data, our model predicts slightly lower values of work hours, with a bigger gap between men and women. For example, Appendix B reports average work hours for those age 25 to 55 using PSID data of 45 hours per week for men, and 38 hours per week for women.

Further results from the model show that men claim Social Security benefits later than women (see Figure $3 \mathrm{C}$ ). Additionally, the demand for life insurance is much higher for men (see Figure $3 \mathrm{~A}$ ). To gain more insight into what drives these results, we turn now to an analysis of single and couple households separately.

Figure 4 presents the expected life cycle profiles for singles. Panel A shows that wealth builds up gradually until age 60, when it amounts to about three times average consumption. Thereafter, these households start to draw down assets to compensate for fewer hour of work. Between age 60 and 80, wealth levels are relatively flat (besides a slight bump around age 66). This occurs for two reasons. First, households gradually claim their Social Security benefits between age 62 and 70, but claimants need not fully leave the labor force. Instead they work part time up to the earnings test exempt amount. Depending on education, this corresponds to about 19 hours per week for high school graduates and 12 hours for college graduates. This explains relatively flat wealth levels up to age 70 . Second, while households begin to decumulate savings after age 70, mortality is also rising. Accordingly, widows and widowers, who hold the higher wealth of richer couple households, increasingly enter the subsample of singles. The transition from couples to singles tends to neutralize the effect of dissaving, on average, which accounts for the relatively flat wealth levels to age 80 .

Figure 4 here

Comparable to the situation for the overall population, the allocation of financial wealth to stocks is relatively constant over the life cycle (35-52\%). Average consumption is lower for singles, but the same overall pattern applies.

The demand for term life insurance among singles is close to zero at all ages. This is because singles lack provisional and bequest motives, since usually there are no children or partners to provide for after death (Hubener et al., 2013). In addition, single households in our baseline model have no pure bequest motive, i.e., they gain no (altruistic) utility from the transfer of wealth to the next generation. Only for single women between age 30 and 40 do 
we observe a positive (but still low) demand for life insurance. This results from divorced women who cannot finance their children's consumption and college education needs solely from their accumulated saving, were they to die. As a result, these women buy life insurance on their own lives, which is very inexpensive early on. We hardly see any life insurance purchases for single men, since the only case for which single men must take care of children is when they are widowers. As the mortality of young women is very low, there are only a very few such cases which do not noticeably affect average life insurance demand for the overall sample.

Turning to labor supply, Figure 4B shows that single men work for pay 42 hours per week at the beginning of their life cycles. Thereafter, they gradually reduce their time on the job to 35 hours just before retirement. From age 62 onward, men begin to claim Social Security benefits that provide them with a safe income stream for life. In conjunction with the possibility of receiving Social Security benefits and working without tax penalties up to the earnings test exempt amount, most men reduce their average work hours sharply and work only part time after claiming, reducing the overall average to 19-31 hours per week. Average paid work hours for women are lower than men's, since women have, on average, lower wage rates. Accordingly, they are less willing to substitute lower leisure time for higher consumption affordable by more work. Another explanation is that the single sample includes divorced women with children, who are financially supported by their ex-husbands and have lower time budgets due to child care responsibilities. The consequence is that these women work less for pay, as compared to single women without children. This explains the slightly increasing gap of paid work hours between men and women age 35-45. In this age group, about $30 \%$ of single women have children. From ages 45 to 55, women increase their labor market work effort slightly because their children become older and require less time (or have left home). After age 60, when children are out of the house, men and women exhibit very similar work patterns.

Panel C of Figure 4 displays Social Security claiming patterns by age. Claiming behavior is very similar by sex: the mean claiming age is 66.1 for men and 66.6 for women, and about 24\% (18\%) of single men (women) claim Social Security benefits at the earliest possible age of 62. These households are unwilling to take advantage of the increased life annuity income by delaying claiming. After a claiming peak at 62 , on average $8 \%$ of singles gradually claim their benefits at each subsequent age until 69. More detailed analysis shows that early claiming households build up relatively low wealth during their working lives and have low permanent wage rates in their 60's. Since the replacement rates under the U.S. 
Social Security System are progressive, poor households with low PIAs due to low lifetime earnings receive a higher replacement rate. This increases incentives to claim the Social Security benefits early and work part time up to the earnings test exempt amount to augment overall income. About 24\% (27\%) of single men (women) delay claiming to age 70 , when claiming is mandatory. On average, these households have a higher permanent wage rate and consequently build up more financial wealth than do poorer, earlier claiming, households. This later claiming pattern arises because they can take advantage of the increased real annuity income from the delayed retirement credits. Moreover, they take advantage of still high wage rates and work longer; claiming later avoids the penalty from the earnings test.

Next, Figure 5 presents life cycle profiles for couples. In Panels A - C, we observe important differences compared to singles. First, wealth and consumption levels are much higher for couples than singles, due to the fact that couple households have multiple members. Interestingly, wealth per adult is also higher for couples: for instance, at age 40, the ratio of average wealth to consumption for couples is 3.5 but only 2.8 for singles. This is because of couples' higher precautionary saving motives due to uncertainty in family status (death, divorce) and having to save for the children's college education. The demand for life insurance is hump-shaped, with insurance purchased mainly on the husband. At age 36, the average face value peaks at around $\$ 105,000$, when most couples have children and many women reduce their labor force hours substantially because of child care. Naturally, the couple will buy insurance to protect against the husband's unexpected early death, so as to finance consumption of the bereaved family and for the children's college. Demand for life insurance on the wife's life is clearly lower than on the husband's. One reason is that female mortality is substantially lower than men's. Moreover, since men have higher wages than women, a widower can more easily provide for his family than can a widow. In addition, the re-marriage rate of widowers with children is more than twice as high as for widows, so widowers are much more likely to find a new partner to help with child care and provide a second income. The demand for life insurance on women age 35-45 is driven by couples with more than two children. In this instance, the death of the wife would impose a substantial burden on the husband, because he would need to curtail his work hours to care for the young children. Life insurance purchases of both partners combined with accumulated liquid savings cover the risk that both parents might die at once.

Figure 5 here

Interestingly, the demand for life insurance during retirement is zero for both partners. Because of generous Social Security widow benefits, retirement income is relatively 
symmetrically distributed between both partners, so only a minor portion of retirement income is lost when one of the spouses dies. If the husband dies first, his surviving widow receives $100 \%$ of his benefits as his widow, an amount typically higher than her own or spousal benefits. In addition, the surviving spouse retains the household's remaining liquid wealth, and as a single needs lower consumption. Therefore the death of one partner need not cause a large consumption shortfall that would need to be hedged by life insurance purchases. This result is in line with Hubener et al. (2013) who also reported no demand for life insurance when the couple's pension income is symmetrically distributed.

The work hour pattern for couples differs distinctly from that of singles. In their early 20's, both husbands and wives work for pay up to 50 hours per week. In contrast to single men, husbands reduce work to 44 hours only around age 40 and they maintain this level until retirement, effectively working about 5 hours per week more than single men. Wives, on the other hand, reduce their market work hours to about 30 per week in their late-30's. From ages 40 to 55, women gradually increase their effort for paid work up to 34 hours per week, when children become older and require less time. Despite their high work hours at younger ages, wives work for pay about 3 fewer hours per week over the life cycle, compared to single women. This specialization of work hours within the family is due to the fact that women's wage rates are lower than men's, on average, and they fall further on the arrival of children. Thus the wife shoulders most of the unpaid burden of child care and home production time, and she works less for pay than the husband. Similar to the situation for singles, both husband and wife start to reduce their market work substantially in their 60's.

Interestingly, couples’ Social Security claiming patterns differ remarkably from those of singles. About $57 \%$ of married women claim their own old-age Social Security benefits at the earliest possible age of 62 . Their mean claiming age is 64.6 , about 2.0 years earlier than single women. By contrast, the mean claiming age for married men is about 67.9 with $61 \%$ delaying claiming up to age 70, much later than for unmarried men.

There are several explanations for these differences. First, married women's PIAs are considerably lower than those of their husbands. ${ }^{40}$ In addition, married women are eligible for spousal benefits and later to relatively generous widow benefits (100\% of the husband's benefit). The Social Security claiming rules also permit the wife to switch from her own old age retirement benefits to spousal benefits and/or to widow benefits when the husband passes away. Spousal benefits increase for every year of delaying after age 62 by about $8 \%$ (up to the

\footnotetext{
40 Since our model assumes the same permanent income for both spouses with the husband's deterministic component being higher and the work hours of women being lower, our simulations do not have any wife with a higher PIA than her husband.
} 
normal retirement age 66). Because of these switching possibilities and particularly due to the generous widow benefits, early claiming for married women only reduces their retirement benefits up to the point of the husband's death. ${ }^{41}$

As a result, for most couples, the optimal strategy to maximize lifetime benefits is for the wife to claim her relatively lower own benefits early, and to claim spousal benefits later if they are higher. In addition, the husband will claim his own old age benefits relatively late in life. This increases his own benefits and also his potential widow's benefits after his death. Because of the high probability that the wife outlives her husband, better widow benefits are important to maximize the couple’s joint lifetime utility.

Such a strategy also effectively hedges longevity risk. If one partner dies, the surviving spouse receives the high benefits of the husband (either directly or as widow benefits) for the rest of his or her life. If both spouses survive for a long time, they continue to receive both incomes, i.e., the own benefit of the husband and the spousal or own benefits of the wife. Even though the benefits for the wife are smaller, the couple profits from the consumption scaling of not having to consume twice as much as a single person.

Coincident with the results for single men, married men's higher permanent wage rates on average produce later claiming patterns. The few households (some 20\%) in which wives delay claiming to age 70 also have very high wage rates. These high-earning women seek to remain in the workforce to generate high labor income and take advantage of the delayed retirement credit by claiming later.

\subsection{Effects of education and children on key financial outcomes}

Next, we explore how differences in education and children influence optimal claiming patterns and portfolio allocation (stocks, bonds, and life insurance). We use our simulation results to distinguish between lesser versus more educated households, and also couples with no children versus those with at least two children. Results are provided in

\footnotetext{
${ }^{41}$ The change in the actuarial present value of retirement benefits caused by the timing of claiming is very different for single and married women, as illustrated in the present value calculations by Coile et al. (2002) and Shoven and Slavov (2012). For instance, assume a single woman claiming retirement benefits at age 62 would receive $\$ 7500$ per year for the rest of her life; this would generate an actuarial present value of $\$ 130,224$ (at a discount rate $2 \%$ and with survival probabilities as in the text). Delaying claiming to age 66 produces higher benefits of $\$ 10,000$ per year (see Table 3) with a present value $4 \%$ higher, of $\$ 135,367$, computed as of age 62 . By contrast, a married woman's benefits consist of two portions: her own old age benefits (or spousal benefits if greater), and her widow benefits when her husband dies. Accordingly, for a married woman with a lower PIA than her husband, the relevant time frame over which she will receive her own old age benefits is not her life expectancy, but rather that of her husband's lifetime, after which she will switch to her higher widow benefits. Assuming the husband is four years older than his wife, if she claimed at 62 this yields a present value of the wife's retirement benefits until his date of death of $\$ 85,772$; by contrast if she were to postpone claiming to 66 , her present value would be only $\$ 77,318$, or $10 \%$ less.
} 
Tables 5, 6 and 7, which touch on (respectively) claiming ages, stock fractions, and life insurance demand.

\section{Tables 5-7 here}

Turning first to the claiming decision, Table 5 indicates the fraction of persons who take Social Security benefits between ages 62 and 70, displayed by education and number of children. Here we see that the model predicts that less-educated women claim much earlier, with an expected claiming age of 64.4 versus 66.2 for the college-educated, By contrast, men's patterns are more similar with an identical average claiming age of 67.3. The relatively high replacement rate under Social Security is particularly generous for low-wage women, whereas higher earning men and college-educated women have more of an incentive to remain employed. Again, it is worth noting that men's optimal claiming age is much higher than for women, driven by the availability of spousal and survivor benefits for married women. Next we compare childless couples and those with children, where we see that claiming patterns are remarkably similar: about $60 \%$ of the women claim as early as possible, and women's expected claiming ages are also virtually identical, regardless of having had children. For men we see a small effect that fathers of two or more children claim a year earlier than childless husbands. Overall, the model implies that education has a stronger effect than children on claiming patterns.

Turning to the results for the share of financial wealth held in equity, Table 6 first reports differences by education, where we see that the less-educated always hold a smaller portion of their portfolios in equities than do the college-educated. This is because the lesseducated are less well-off, and so, at all ages, they must hold relatively more of their overall financial wealth in a non-risky transaction account to finance current consumption. Accordingly, this diminishes their ability to invest in stocks. Turning to results on couples, we see that the young and the old hold similar stock fractions. But couples with children are much less invested in equity during middle age, as they must use their assets to pay for college. Specifically, couples age 45-64 with children hold 13-14 percentage points less in equities. Overall, though the equity share does vary with education and family status, the profile is rather smooth by age, by contrast to other studies generating equity profiles over the life cycle.

Life insurance holdings vary across the life cycle and by household type. First, the peak age for purchase is when the children are young; after age 65, there is effectively no demand for further insurance since Social Security benefits provide a generous replacement rate to those losing their spouses. Second, those with lower wages buy relatively more life 
insurance (as a multiple of their full-time labor income), than the college-educated. This is because high school educated couples with children seek to insure against the loss of the husband's income in the event of his death. While these wives could return to the labor market, their low wages would be less than needed to smooth consumption, compared to the college-educated women. Couples without children buy no insurance on wives, but they do carry an insurance face value of up to $150 \%$ of the full-time labor earnings on the husbands. This is because the wife's low wage rates induce her to spend more time at home; the loss of her husband may induce more work on her part, but his demise still imposes substantial financial risk on the couple, driving her to require more insurance on his life. By contrast, couples with 2+ children demand much more insurance while the children are young, particularly on the husbands, inasmuch as the wives are devoting much of their time to home production and not earning much.

\subsection{Empirical evidence on claiming patterns}

As noted above, four stylized facts flowed from our normative model regarding Social Security claiming patterns. First, married women claim much earlier than single women. Second, married women claim much earlier than married men. Third, more educated women claim later than less educated women. Finally, children have little impact on men and women’s claiming patterns.

To ascertain whether our predictions are in line with empirical behavior, we conduct an empirical analysis of actual Social Security claiming patterns in the Health and Retirement Study (HRS), a nationally representative longitudinal survey of Americans over the age of 50, followed over the period 1992-2010. ${ }^{42}$ The Social Security claiming age is defined as the number of months elapsed between turning age 62 and benefit receipt, which we regress on a vector of arguably exogenous explanatory variables which our model indicates are importantly associated with claiming patterns. These include sex, marital status, number of living children $(0,1,2,3+)$, and educational attainment (at least some college versus none). To test whether claiming patterns are differentiated by sex, we interact all variables with a Male coefficient, implying that the basic estimates refer to women.

\footnotetext{
${ }^{42}$ For more information on the HRS, see http://hrsonline.isr.umich.edu/. Our dataset is similar to that of Shoven and Slavov (2012, 2013) who kindly provided their computer code for the extract and variable definitions. Since that study could not differentiate between retired worker, spouse/survivor, and disability benefits, the authors excluded all persons who claimed younger than age 62, older than age 70, who never claimed age 62-70, who reported being widowed prior to claiming Social Security, or who ever received disability benefits. Our sample size is slightly larger due to the addition of the 2010 wave.
} 
Our Tobit coefficient estimates and standard errors are reported in Table 8. The average claiming age in the HRS dataset is $63.4,^{43}$ but married women claim substantially earlier (-6.92 months) than single women and the result is statistically significant. This is precisely what our theoretical model predicts, though the magnitude is somewhat smaller than what was generated in our simulations. Moreover, better-educated women claim later than women with no college (+4.53 months), again a statistically significant finding and one consistent with our hypotheses. Married men also claim later than married women $(+6.89$ months) again a statistically significant result, and one compatible with our model. Finally, we find no significant effects of children on women's (or men's) claiming patterns, a result that again agrees with our hypotheses. In sum, the key variables having an influential effect in our model simulations also matter empirically as well.

\section{Policy Simulations}

Finally, we use our calibrated theoretical model to examine a pair of policy reforms, namely the elimination of spousal versus widow benefits. This exercise, while only a hypothetical simulation, is in keeping with the spirit of research by Gustman and Steinmeier (2001), who argue that these benefits substantially undermine the progressivity of the Social Security system.

Table 9 reports results from two simulations: one of which evaluates the life cycle impact of omitting spouse benefits, and the other of eliminating widow benefits. The first row shows, compared to the base case, that wives' claiming ages are not affected by the removal of the spouse benefits. The reason is that most women have acquired substantial retirement benefits themselves and do not depend on spousal benefits. By contrast, when widow benefits are eliminated, this has a substantial impact on claiming: women would delay to almost age 70 , on average, and also work additional weekly hours. This is due to the fact that women are now exposed to a substantial risk of uninsured widowhood, since they now have only their single annuity on which to rely over their relatively long old age period. Moreover, the Social Security delayed retirement credit now becomes more salient for women since, under the law, the own benefit adjustment for deferral is computed using a unisex table. When no widow benefit is available, women do better by deferring their claiming age than when they can fall back on a widow benefit. As noted above, when widow benefits are available, the typical woman's rewards from delaying claiming are only relevant until the death of her husband, so

\footnotetext{
${ }^{43}$ The HRS average claiming age is lower than that in our simulation model of 65.7, but we are interested in the qualitative rather than the exact quantitative magnitudes here. Moreover, the HRS dataset includes different birth cohorts that experienced quite different economic environments through time.
} 
deferring benefits increments her benefit flow for a relatively short period. If widow benefits are eliminated, the time period over which the woman receives the deferral increment expands, making delayed claiming more consequential.

Table 9 here

By contrast, Table 9 shows that men's claiming patterns and work hours are relatively unaffected by cutting spouse benefits, since few men would have received spousal benefits in any event. By contrast, if widow benefits were to be eliminated, men claim much earlier - by 1.2 years - and they work fewer hours. This is because the husband's additional work and deferred claiming would no longer boost his wife's payouts after his death. Moreover, the household optimally buys more life insurance on the husband; they do so until the wife claims, since her own benefit thereafter is sufficiently high to support her in old age.

Interestingly, neither policy simulation has a measurable impact on the equity share. This is sensible, inasmuch as the household relies on altering Social Security claiming patterns, in effect "purchasing” a higher annuity benefit over the remaining lifetime. In other words, the structure of Social Security options affords the household an alternative to saving more and changing its stock allocation.

\section{Conclusions}

This paper show how accounting for the impact of family and Social Security in a life cycle setting profoundly influences household asset allocation, work and retirement decisions, and life insurance purchases. Our model builds on previous research by including stochastic equity returns and labor income, as well as mortality risk. But we extend prior studies by incorporating the impact of demographic transitions on household budgets, such that the costs of children include peoples' direct as well as indirect time and money constraints. Additionally, we track men and women prior to, during, and after marriage, and we evaluate the impacts of having children as well as college education costs. Most importantly, our formulation of Social Security benefit options is more realistic than previous portfolio life cycle studies that assumed retirement benefits are simply equal to a fixed proportion of the last labor income as of some pre-specified date. Not only do we model own benefits as a function of the individual's lifetime earnings history and the age of benefit claiming, but we also model spousal and survivor payments. In this way, we acknowledge the possibility that a spouse can claim first on her own account, and later switch to alternative benefit payment options. 
These factors interact in complex ways with Social Security benefit optionalities, and these in turn shape optimal saving, portfolio, and work decisions over the life cycle. We realistically calibrate the model, drawing on empirical evidence on time use, demographics, and wage rates. Our model produces reasonable saving and wealth profiles, along with low and stable equity fractions consistent with empirical evidence. We also predict and confirm in longitudinal data that Social Security rules induce married women to claim retirement benefits much earlier than single women and married men. Moreover, our policy simulations imply that changing Social Security rules will have a substantial impact on household financial behavior. Specifically, our policy simulation finds that eliminating widows' Social Security benefits would dramatically narrow claiming differences between men and women, while substantially increasing men's life insurance purchases. 


\section{References}

Abel, A.B., J.C. Eberly, and S. Panageas. (2013). Optimal Inattention to the Stock Market with Information Costs and Transactions Costs. Econometrica. 81(4): 1455-1481.

Aguiar, M. and E. Hurst (2005). Consumption vs. Expenditure. Journal of Political Economy. 113(5): 919-948.

American Academy of Actuaries. (2002). Final Report of the American Academy of Actuaries' Commissioners Standard Ordinary Task Force, American Academy of Actuaries, Washington, DC

Ameriks, J., and S. P. Zeldes. (2004). How Do Household Portfolio Shares Vary with Age? Working Paper, Columbia University GSB.

Arias, E. (2010). United States Life Tables, 2005. National Vital Statistics Reports. 58(10).

Baumol, W.J. (1952). The Transactions Demand for Cash. Quarterly Journal of Economics. 67(4): 545-556.

Bernheim, B. D., J. Skinner, and S. Weinberg. (2001). What Accounts for the Variation in Retirement Wealth Among U.S. Households? American Economic Review. 91(4): 832-857.

Bodie, Z., R. Merton, and W. Samuelson (1992). Labor Supply Flexibility and Portfolio Choice in a Life Cycle Model. Journal of Economic Dynamics and Control. 16: 427449 .

Brown, J., A. Kapteyn, O. S. Mitchell, and T. Mattox. (2013). Framing the Social Security Earnings Test. Pension Research Council Working Paper. Wharton School.

Campbell, J. and L. Viceira (2001). Who Should Buy Long-Term Bonds? American Economic Review. 91: 99-127.

Carroll, C. D., and A. A. Samwick. (1997). The Nature of Precautionary Wealth. Journal of Monetary Economics, 40(1): 41-71.

Chai, J., W. Horneff, R. Maurer, and O. S. Mitchell. (2011). Optimal Portfolio Choice over the Life Cycle with Flexible Work, Endogenous Retirement, and Lifetime Payouts. Review of Finance. 15(4): 875-907.

Citro, C. F., and R. T. Michael (1995). Measuring Poverty: A New Approach. Washington, DC: National Academy Press.

Cocco, J.F. (2005). Portfolio Choice in the Presence of Housing. Review of Financial Studies. 18(2): 535-567.

Cocco, J., F. Gomes, and P. Maenhout. (2005). Consumption and Portfolio Choice over the Life Cycle. Review of Financial Studies. 18(2): 491-533.

Coile, C., P.A. Diamond, J. Gruber, and A. Jouston. (2002). Delays in claiming Social Security benefits, Journal of Public Economics. 84: 357-385.

Copen, C.E., K. Daniels, J. Vespa, and W.D. Mosher. (2012). First Marriages in the United States: Data From the 2006-2010 National Survey of Family Growth. National Health Statistics Reports. 49.

Farhi, E. and S. Panageas. (2007). Saving and Investing for Early Retirement: A Theoretical Analysis. Journal of Financial Economics. 83(1): 87-121. 
French, E. (2005). The Effects of Health, Wealth, and Wages on Labor Supply and Retirement. Review of Economic Studies. 72(2): 395-427

Gomes, F. J., L. J. Kotlikoff, and L. M. Viceira. (2008). Optimal Life-Cycle Investing with Flexible Labor Supply: A Welfare Analysis of Life-Cycle Funds. American Economic Review: Papers \& Proceedings. 98(2): 297-303

Gomes, F., and A. Michaelides (2005). Optimal Life-Cycle Asset Allocation: Understanding the Empirical Evidence. Journal of Finance. 60(2): 869-904.

Gronau, R. (1977). Leisure, Home Production, and Work - the Theory of the Allocation of Time Revisited. Journal of Political Economy. 85(6): 1099-1123

Guiso, L., M. Haliassos, and T. Jappelli. (2002). Household Portfolios. MIT Press, Cambridge, MA.

Gustman, A. L., and T. L. Steinmeier (2001). How Effective is Redistribution under the Social Security Benefit Formula? Journal of Public Economics. 82(1): 1-28

Gustman, A. L. and T. L. Steinmeier (2005). The Social Security Early Entitlement Age in a Structural Model of Retirement and Wealth. Journal of Public Economics 89(2-3): 441- 463.

Gustman, A. L., T. L. Steinmeier, and N. Tabatabai (2010). What the Stock Market Decline Means for the Financial Security and Retirement Choices of the Near-Retirement Population. Journal of Economic Perspectives. 24(1): 161-182.

Hamermesh, D. S., H. Frazis, and J. Stewart. (2005). Data Watch: The American Time Use Survey. Journal of Economic Perspectives. 19(1): 221-232

Horneff, W., R. Maurer, and M. Z. Stamos. (2008). Life-Cycle Asset Allocation with Annuity Markets. Journal of Economic Dynamics and Control. 32(11): 3590-3612

Hubener, A., R. Maurer, R. Rogalla. (2013). Optimal Portfolio Choice with Annuities and Life Insurance for Retired Couples. Review of Finance. Forthcoming

Inkmann, J., P. Lopez, and A. Michaelides. (2011). How deep is the annuity market participation puzzle? Review of Financial Studies 24, 279-319.

Kimmel, J. and R. Connelly. 2007. Determinants of Mothers' Time Choices in the United States: Caregiving, Leisure, Home Production, and Paid Work. Journal of Human Resources. 42(3): 643-681.

Love, D. (2010). The Effects of Marital Status and Children on Savings and Portfolio Choice. Review of Financial Studies. 23(1): 385-432.

Martin, J.A., B.E. Hamilton, S.J. Ventura, M.J.K. Osterman, S. Kirmeyer, T.J. Mathews, and E.C. Wilson. (2011). Births: Final Data for 2009. National Vital Statistics Reports. 60(1)

Merton, R.C. (1969). Lifetime Portfolio Selection under Uncertainty: The Continuous-Time Case. Review of Economics and Statistics 51(3), 247-257.

Myers, R. (1985). Social Security. $3^{\text {rd }}$ edition, McCahan Foundation.

Scholz, K., A. Seshadri, and S. Khitatrakum. (2006). Are Americans Saving “Optimally“ for Retirement? Journal of Political Economy 114(4): 607-643.

Scholz, K. and A. Seshadri. (2007). Children and Household Wealth. University of Michigan Retirement Research Center Working Paper. 2007-158. 
Shoven., J.B. and S.N. Slavov. (2012). The Decision to Delay Social Security Benefits: Theory and Evidence. NBER WP. 17866.

Shoven, J. B. and S. N. Slavov. (2013). Recent Changes in the Gains from Delaying Social Security. NBER WP. 19370.

Smith, K. E., M. M. Favreault, B.A. Butrica, and P. Issa. (2010). Modeling Income in the Near Term, Version 6. The Urban Institute, Final Report.

Turley, R.N.L., and M. S. Desmond. (2006). Contributions to College Costs by Married and Divorced Parents. Institute for Research on Poverty Working Paper, University of Wisconsin-Madison.

Viceira, L. (2001). Optimal Portfolio Choice for Long-Horizon Investors with Non-tradable Labor Income. Journal of Finance. 56(2): 433-470.

Wachter, J.A., and M. Yogo (2010). Why Do Household Portfolio Shares Rise in Wealth? Review of Financial Studies, 2010, 23(11): 3929-3965 


\section{Table 1: Child Care Time Regression Results.}

This table presents regression results of hours spent on home production per working day using ATUS data from waves 2003-2011. Standard errors are given in brackets and the number of stars indicates levels of significance $(10 \%, 5 \%, 1 \%)$. The regression constant represents the time a person without children would dedicate to home production. The coefficients for the different child dummies give the increase of this time by the number of children under 18 present in the household. The effect of children's ages is captured by the polynomial in 18-aoy (18 minus age of the youngest child), which is the number of years until the youngest child will turn 18 years old (18-aoy equals zero, if no child is present).

\begin{tabular}{|c|c|c|c|c|}
\hline & $\begin{array}{l}\text { Married } \\
\text { Women }\end{array}$ & Married Men & Single Women & Single Men \\
\hline \multirow[t]{2}{*}{ Constant } & $3.282 * * *$ & $1.939 * * *$ & $2.462 * * *$ & $1.805^{* * *}$ \\
\hline & $(0.047)$ & $(0.04)$ & $(0.036)$ & $(0.033)$ \\
\hline \multirow{2}{*}{ (18-аоу) / 10} & $3.928 * * *$ & 0.299 & -0.677 & $2.531^{* * *}$ \\
\hline & $(0.975)$ & $(0.301)$ & $(0.565)$ & $(0.796)$ \\
\hline \multirow[t]{2}{*}{$(18 \text {-аоу })^{2} / 100$} & $\begin{array}{l}- \\
4.622 * * *\end{array}$ & 0.126 & $0.842^{* * *}$ & $-1.103 * *$ \\
\hline & $(1.118)$ & $(0.142)$ & $(0.279)$ & $(0.432)$ \\
\hline \multirow[t]{2}{*}{$(18 \text {-аoу })^{3} / 1000$} & $1.857 * * *$ & & & \\
\hline & $(0.375)$ & & & \\
\hline \multirow[t]{2}{*}{1 child } & -0.073 & 0.171 & $1.379 * * *$ & -0.037 \\
\hline & $(0.237)$ & $(0.135)$ & $(0.247)$ & $(0.311)$ \\
\hline \multirow[t]{2}{*}{2 children } & $0.585^{* *}$ & $0.359 * *$ & $1.947 * * *$ & 0.155 \\
\hline & $(0.261)$ & $(0.155)$ & $(0.281)$ & $(0.381)$ \\
\hline \multirow[t]{2}{*}{$3+$ children } & $1.181^{* * *}$ & $0.518^{* * *}$ & $2.293 * * *$ & -0.129 \\
\hline & $(0.273)$ & $(0.17)$ & $(0.313)$ & $(0.481)$ \\
\hline Number of obs. & 10828 & 11757 & 7806 & 5730 \\
\hline $\begin{array}{l}\text { Number of obs. } \\
\text { with children }\end{array}$ & 6707 & 8122 & 2953 & 815 \\
\hline R squared & $12.09 \%$ & $2.64 \%$ & $14.08 \%$ & $3.20 \%$ \\
\hline
\end{tabular}




\section{Table 2: Wage Rate Regression Results.}

This table shows regression results of the natural logarithm of the wage rate using PSID data for respondents age 25-65 from waves 1995-2009 and the corresponding estimates of variances of permanent and transitory shocks to the log wage rate. Standard errors are given in brackets and the number of stars indicates levels of significance $(10 \%, 5 \%, 1 \%)$. The coefficients for wave dummies are not shown. The independent variables are a second order polynomial in the worker's age, dummies for the number of children under 18 present in the household, presence of a spouse in the household, and dummies for part time work (less than 20 hours per week) and overtime work (more than 40 hours a week). Shock variances are estimated by regressing the squared difference in unexplained log wage between waves on the time lag between waves and a constant vector.

\begin{tabular}{|c|c|c|c|c|}
\hline Coefficient Estimates & $\begin{array}{c}\text { Men, } \\
\text { High School }\end{array}$ & $\begin{array}{l}\text { Women, } \\
\text { High School }\end{array}$ & $\begin{array}{l}\text { Men, } \\
\text { College }\end{array}$ & $\begin{array}{l}\text { Women, } \\
\text { College }\end{array}$ \\
\hline \multirow[t]{2}{*}{ Constant } & $1.669 * * *$ & $1.974 * * *$ & $1.624 * * *$ & $1.968 * * *$ \\
\hline & $(0.063)$ & $(0.063)$ & $(0.095)$ & $(0.084)$ \\
\hline \multirow[t]{2}{*}{ Age / 100} & $4.221 * * *$ & $2.470 * * *$ & $5.831 * * *$ & $4.335^{* * *}$ \\
\hline & $(0.318)$ & $(0.318)$ & $(0.489)$ & $(0.436)$ \\
\hline \multirow[t]{2}{*}{$\mathrm{Age}^{2} / 10000$} & $-3.933 * * *$ & $-2.448 * * *$ & $-5.285 * * *$ & $-4.400 * * *$ \\
\hline & $(0.388)$ & $(0.381)$ & $(0.588)$ & $(0.531)$ \\
\hline \multirow[t]{2}{*}{1 child } & 0.006 & $-0.036 * * *$ & $0.028 *$ & $-0.057 * * *$ \\
\hline & $(0.010)$ & $(0.010)$ & $(0.014)$ & $(0.013)$ \\
\hline \multirow[t]{2}{*}{2 children } & $0.034 * * *$ & $-0.058 * * *$ & $0.076^{* * *}$ & $-0.050 * * *$ \\
\hline & $(0.010)$ & $(0.011)$ & $(0.015)$ & $(0.014)$ \\
\hline \multirow[t]{2}{*}{ 3+ children } & 0.017 & $-0.122 * * *$ & $0.041 * *$ & $-0.103 * * *$ \\
\hline & $(0.013)$ & $(0.013)$ & $(0.019)$ & $(0.019)$ \\
\hline \multirow[t]{2}{*}{ Spouse present } & $0.113^{* * *}$ & $0.092 * * *$ & $0.126^{* * *}$ & $0.124^{* * *}$ \\
\hline & $(0.011)$ & $(0.008)$ & $(0.016)$ & $(0.010)$ \\
\hline \multirow[t]{2}{*}{ Part time work } & $-0.217^{* * *}$ & $-0.106^{* * *}$ & $-0.167 * *$ & $-0.086^{* * *}$ \\
\hline & $(0.056)$ & $(0.023)$ & $(0.072)$ & $(0.028)$ \\
\hline \multirow[t]{2}{*}{ Overtime work } & $0.063 * * *$ & $0.076^{* * *}$ & $0.039 * * *$ & $0.022 * *$ \\
\hline & $(0.007)$ & $(0.010)$ & $(0.010)$ & $(0.010)$ \\
\hline Shock variances & \multicolumn{2}{|c|}{ High School } & \multicolumn{2}{|c|}{ College } \\
\hline \multirow[t]{2}{*}{ Permanent } & \multicolumn{2}{|c|}{$0.0069 * * *$} & \multicolumn{2}{|c|}{$0.0135^{* * *}$} \\
\hline & \multicolumn{2}{|c|}{$(0.0008)$} & \multicolumn{2}{|c|}{$(0.0013)$} \\
\hline \multirow[t]{2}{*}{ Transitory } & \multicolumn{2}{|c|}{$0.0317 * * *$} & \multicolumn{2}{|c|}{$0.0321^{* * *}$} \\
\hline & \multicolumn{2}{|c|}{$(0.0019)$} & \multicolumn{2}{|c|}{$(0.0028)$} \\
\hline
\end{tabular}




\section{Table 3: Early claiming reductions and delayed retirement credits}

The second line reports the old age retirement benefits as a multiple of the Primary Insurance Amount in dependence of the claiming age. The third line reports the spousal benefits in relation to the partner's benefits (excluding delayed retirement credit) in dependence of the age when the spousal benefits are claimed. All values are calculated according to U.S. Social Security rules (Myers, 1985) with a Full Retirement Age of 66.

\begin{tabular}{lccccccccc}
\hline & \multicolumn{10}{c}{ Claiming age } \\
\hline & 62 & 63 & 64 & 65 & 66 & 67 & 68 & 69 & 70 \\
\hline $\begin{array}{l}\text { Old age retirement } \\
\text { benefits }\end{array}$ & $75 \%$ & $80 \%$ & $86.7 \%$ & $93.3 \%$ & $100 \%$ & $108 \%$ & $116 \%$ & $124 \%$ & $132 \%$ \\
$\begin{array}{l}\text { Spousal benefits } \\
\text { 35\% }\end{array}$ & $37.5 \%$ & $41.7 \%$ & $45.8 \%$ & $50 \%$ & $50 \%$ & $50 \%$ & $50 \%$ & $50 \%$ \\
\hline
\end{tabular}

\section{Table 4. Average relative frequencies of family states generated from simulation of transition matrix $\Pi_{\mathrm{ij}, \mathrm{t}}$.}

The simulation starts with $40 \%$ single women, $40 \%$ single men, and $20 \%$ couples (all without children present in the household). The given categories encompass the following family states numbers as given in the appendix (table A1): single women without children - 1,7,15,34; single women with children - 8-10,16-18; single men without children - 2,11-14,19,35; single men with children: 20-22 (note: for divorced men children stay with their mother, only widowers have children present in the household); couple without children - 3,23,24-28,28-33; couple with children - 4-6. All life cycle simulations are based on this population model.

\begin{tabular}{cccccccc}
\hline & \multicolumn{7}{c}{ Age } \\
\hline & $20-29$ & $30-39$ & $40-49$ & $50-59$ & $60-69$ & $70-79$ & $80+$ \\
\hline $\begin{array}{c}\text { Single women } \\
\text { without children }\end{array}$ & $27 \%$ & $13 \%$ & $11 \%$ & $16 \%$ & $20 \%$ & $28 \%$ & $66 \%$ \\
$\quad$ with children & $1 \%$ & $3 \%$ & $5 \%$ & $1 \%$ & $<0.1 \%$ & $0 \%$ & $0 \%$ \\
\hline $\begin{array}{c}\text { Single men } \\
\text { without children }\end{array}$ & $30 \%$ & $19 \%$ & $16 \%$ & $16 \%$ & $16 \%$ & $17 \%$ & $16 \%$ \\
$\quad$ with children & $<0.1 \%$ & $<0.1 \%$ & $<0.1 \%$ & $<0.1 \%$ & $<0.1 \%$ & $0 \%$ & $0 \%$ \\
\hline Couples & & & & & & & \\
$\quad$ without children & $24 \%$ & $21 \%$ & $31 \%$ & $59 \%$ & $65 \%$ & $55 \%$ & $19 \%$ \\
$\quad$ with children & $17 \%$ & $43 \%$ & $37 \%$ & $8 \%$ & $<0.1 \%$ & $0 \%$ & $0 \%$ \\
\hline
\end{tabular}




\section{Table 5: Effect of education and children on Social Security claiming decisions}

This table shows the frequency of claiming ages for Social Security benefits by sex. The life cycle simulation method is identical to that used in Section 4.2 (see notes to Figure 3). Results are shown for the different education subgroups (high school and college) as well as couples without children and with two or more children (the corresponding households either never had any children or had two or more children at some point in their life cycles).

\begin{tabular}{lrrrrrrrr}
\hline & \multicolumn{2}{c}{$\begin{array}{c}\text { High school } \\
\text { education }\end{array}$} & \multicolumn{2}{c}{$\begin{array}{c}\text { College } \\
\text { education }\end{array}$} & $\begin{array}{c}\text { Couples without } \\
\text { children }\end{array}$ & $\begin{array}{c}\text { Couples with 2+ } \\
\text { children }\end{array}$ \\
\cline { 2 - 9 } Claiming age & Women & Men & Women & Men & Women & Men & Women & Men \\
\hline 62 & $54 \%$ & $16 \%$ & $31 \%$ & $20 \%$ & $58 \%$ & $13 \%$ & $62 \%$ & $14 \%$ \\
63 & $3 \%$ & $3 \%$ & $3 \%$ & $4 \%$ & $3 \%$ & $2 \%$ & $2 \%$ & $3 \%$ \\
64 & $6 \%$ & $5 \%$ & $6 \%$ & $4 \%$ & $5 \%$ & $2 \%$ & $3 \%$ & $4 \%$ \\
65 & $5 \%$ & $6 \%$ & $5 \%$ & $4 \%$ & $3 \%$ & $3 \%$ & $3 \%$ & $4 \%$ \\
66 & $3 \%$ & $7 \%$ & $2 \%$ & $4 \%$ & $1 \%$ & $7 \%$ & $1 \%$ & $5 \%$ \\
67 & $5 \%$ & $5 \%$ & $5 \%$ & $4 \%$ & $3 \%$ & $1 \%$ & $2 \%$ & $3 \%$ \\
68 & $5 \%$ & $6 \%$ & $7 \%$ & $5 \%$ & $4 \%$ & $3 \%$ & $3 \%$ & $4 \%$ \\
69 & $7 \%$ & $6 \%$ & $8 \%$ & $6 \%$ & $7 \%$ & $4 \%$ & $5 \%$ & $6 \%$ \\
70 & $13 \%$ & $45 \%$ & $33 \%$ & $51 \%$ & $16 \%$ & $66 \%$ & $19 \%$ & $57 \%$ \\
\hline Avg. claiming age & 64.4 & 67.3 & 66.2 & 67.3 & 64.4 & 68.8 & 64.4 & 67.8
\end{tabular}




\section{Table 6: Effect of education and children on stock holdings as a fraction of financial wealth}

This table shows average stock holdings as a fraction of financial wealth for persons in different age groups. The life cycle simulation method is identical to that used in Section 4.2 (see notes to Figure 3). Results are shown for the different education subgroups (high school and college) as well as couples without children and with two or more children (the corresponding households either never had any children or had two or more children at some point in their life cycles).

\begin{tabular}{lcccc}
\hline Age & $\begin{array}{c}\text { High school } \\
\text { education }\end{array}$ & $\begin{array}{c}\text { College } \\
\text { education }\end{array}$ & $\begin{array}{c}\text { Couples without } \\
\text { children }\end{array}$ & $\begin{array}{c}\text { Couples with } \\
2+\text { children }\end{array}$ \\
\hline $25-34$ & $45 \%$ & $54 \%$ & $58 \%$ & $60 \%$ \\
$35-44$ & $52 \%$ & $60 \%$ & $61 \%$ & $57 \%$ \\
$45-54$ & $47 \%$ & $56 \%$ & $59 \%$ & $45 \%$ \\
$55-64$ & $38 \%$ & $52 \%$ & $52 \%$ & $39 \%$ \\
$65-74$ & $44 \%$ & $52 \%$ & $52 \%$ & $47 \%$ \\
$75-84$ & $45 \%$ & $48 \%$ & $50 \%$ & $47 \%$ \\
\hline
\end{tabular}

\section{Table 7: Normalized life insurance values}

This table shows average life insurance face values by sex for different age groups. The values are given as multiples of the spouse's income assuming full time work (40 hours per week). The life cycle simulation method is identical to that used in Section 4.2 (see notes to Figure 3). Results are shown for the different education subgroups (high school and college) as well as couples without children and with two or more children (the corresponding households either never had any children or had two or more children at some point in their life cycles).

\begin{tabular}{lccccccccc}
\hline & \multicolumn{2}{c}{$\begin{array}{c}\text { High school } \\
\text { education }\end{array}$} & \multicolumn{2}{c}{$\begin{array}{c}\text { College } \\
\text { education }\end{array}$} & \multicolumn{2}{c}{$\begin{array}{c}\text { Couples without } \\
\text { children }\end{array}$} & \multicolumn{2}{c}{$\begin{array}{c}\text { Couples with 2+ } \\
\text { children }\end{array}$} \\
\cline { 2 - 9 } Age & Women & Men & Women & Men & Women & Men & Women & Men \\
\hline $25-34$ & 0.08 & 0.69 & 0.06 & 0.53 & 0.00 & 0.39 & 0.13 & 1.67 \\
$35-44$ & 0.38 & 1.54 & 0.21 & 1.12 & 0.00 & 1.50 & 0.71 & 2.58 \\
$45-54$ & 0.18 & 1.19 & 0.10 & 0.86 & 0.01 & 1.35 & 0.36 & 1.71 \\
$55-64$ & 0.00 & 0.58 & 0.00 & 0.43 & 0.00 & 0.68 & 0.00 & 0.82 \\
$65-74$ & 0.00 & 0.03 & 0.00 & 0.04 & 0.00 & 0.05 & 0.00 & 0.06 \\
\hline
\end{tabular}




\section{Table 8: Empirical analysis of Social Security claiming behavior}

Our analysis is based on the HRS sample constructed by Shoven and Slavov (2012, 2013) and extended for the 2010 wave. The dependent variable refers to the number of months after age 62 that the respondent claimed Social Security benefits. The regression approach uses Tobit estimation since the lower bound of the dependent variable is zero. Explanatory variables are measured as of age 62 and include Married: self-reported being married (versus single); College: at least some college (versus none); Children: number of living children (versus 0); Male (versus Female); other terms are interactions as indicated. The mean of the dependent variable is 16.9 months, for an average claiming age of 63.4. Standard errors are given in brackets below the coefficients and the number of stars indicates levels of significance $(10 \%, 5 \%, 1 \%)$. See text for further discussion.

\begin{tabular}{ll}
\hline \multicolumn{2}{c}{ Months After Age 62 To } \\
Claiming Social Security Benefits \\
\hline Married & $-6.915^{* * *}$ \\
& $(1.183)$ \\
College & $4.527^{* * *}$ \\
& $(0.944)$ \\
1 child & 3.239 \\
& $(2.698)$ \\
2 children & 3.159 \\
& $(2.208)$ \\
$3+$ children & 2.100 \\
& $(2.07)$ \\
Male & -0.525 \\
& $(3.183)$ \\
Male $\times$ married & $6.888^{* * *}$ \\
& $(1.925)$ \\
Male $\times$ college & 1.077 \\
& $(1.343)$ \\
Male $\times 1$ child & -1.862 \\
Male $\times 2$ children & $(3.969)$ \\
Male $\times 3+$ children & -2.982 \\
Constant & $(3.304)$ \\
\hline Number of & -0.860 \\
observations & $(3.136)$ \\
\hline & $15.235^{* * *}$ \\
$(2.023)$
\end{tabular}


Table 9: Simulated behavioral effects of eliminating Social Security spouse or survivor benefit

This table shows average claiming age, life insurance face values, paid work hours, and asset allocations for the base case parameterization, a case with no spousal benefits, and a case with no survivor benefits. The same simulation method is used as in Section 4.2 (see notes to Figure 3). The simulations for the latter two cases are based on new optimal feedback controls which account for the removal of the corresponding benefits. Averages are shown for the subgroup of couples in the 50-69 age bracket.

\begin{tabular}{lccc}
\hline & $\begin{array}{c}\text { Base } \\
\text { Case }\end{array}$ & $\begin{array}{c}\text { No Spousal } \\
\text { Benefits }\end{array}$ & $\begin{array}{c}\text { No Survivor } \\
\text { Benefits }\end{array}$ \\
\hline Wife's avg. claiming age & 64.6 & 64.6 & 69.1 \\
Husband's avg. claiming age & 67.9 & 68.0 & 66.7 \\
Average over Ages 50-69 & & & \\
$\quad$ Wife's life insurance (\$000) & 0.1 & 0.1 & 0.1 \\
$\quad$ Husband's life insurance (\$000) & 29.3 & 29.3 & 46.3 \\
$\quad$ Wife's work hours & 28.7 & 28.9 & 33.7 \\
$\quad$ Husband's work hours & 40.0 & 39.9 & 38.1 \\
$\quad$ Stock allocation & $48 \%$ & $48 \%$ & $49 \%$ \\
\hline
\end{tabular}




\section{Home Production Time}

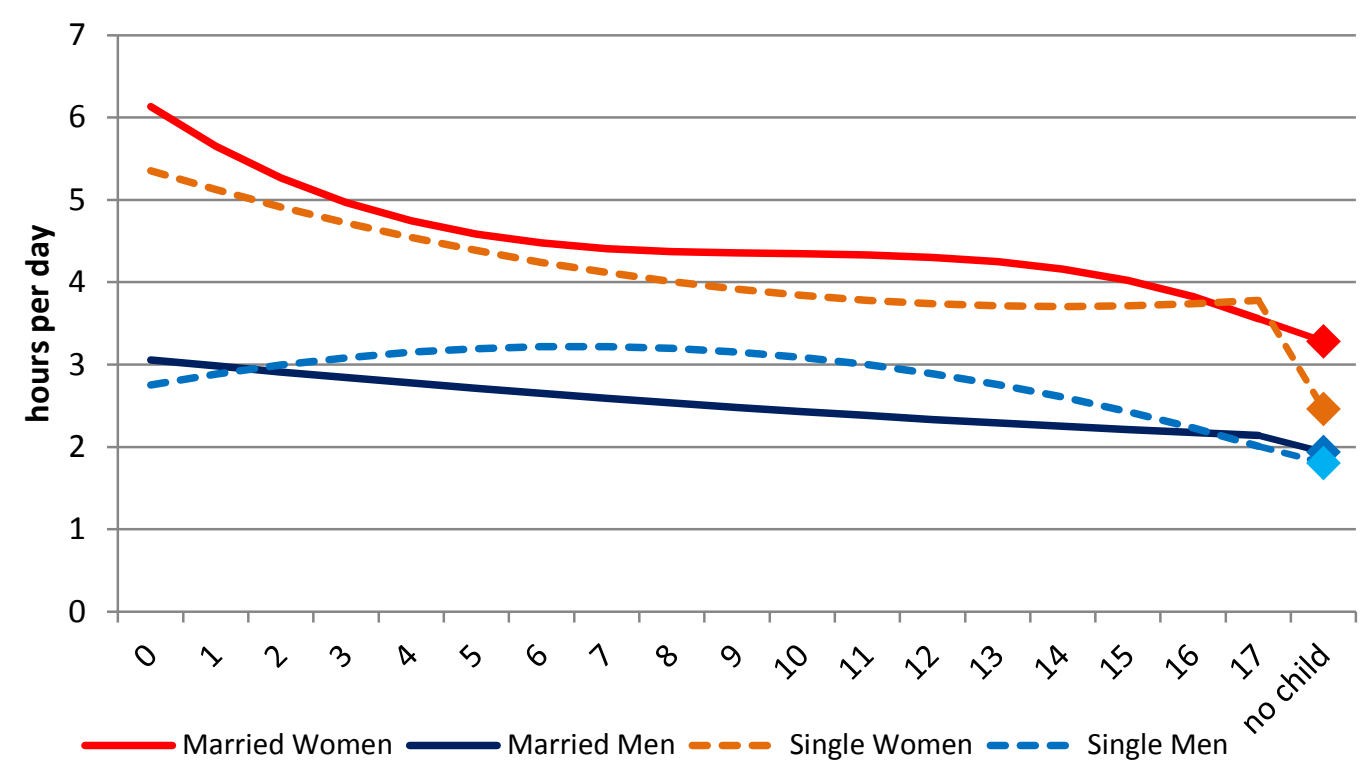

\section{Figure 1: Time Spent on Home Production by Age of Youngest Child.}

This is a graphical representation of results from the wage regression in Table 1. Time spent on home production is shown for the case of one child in the household. For each of the four subsamples, the last data point gives the home production time if no child is present. In the life cycle model, only the difference in these levels is used for the parameterization of child care time $\theta_{s, t}^{i}$.

\section{Hourly Wage Profiles}

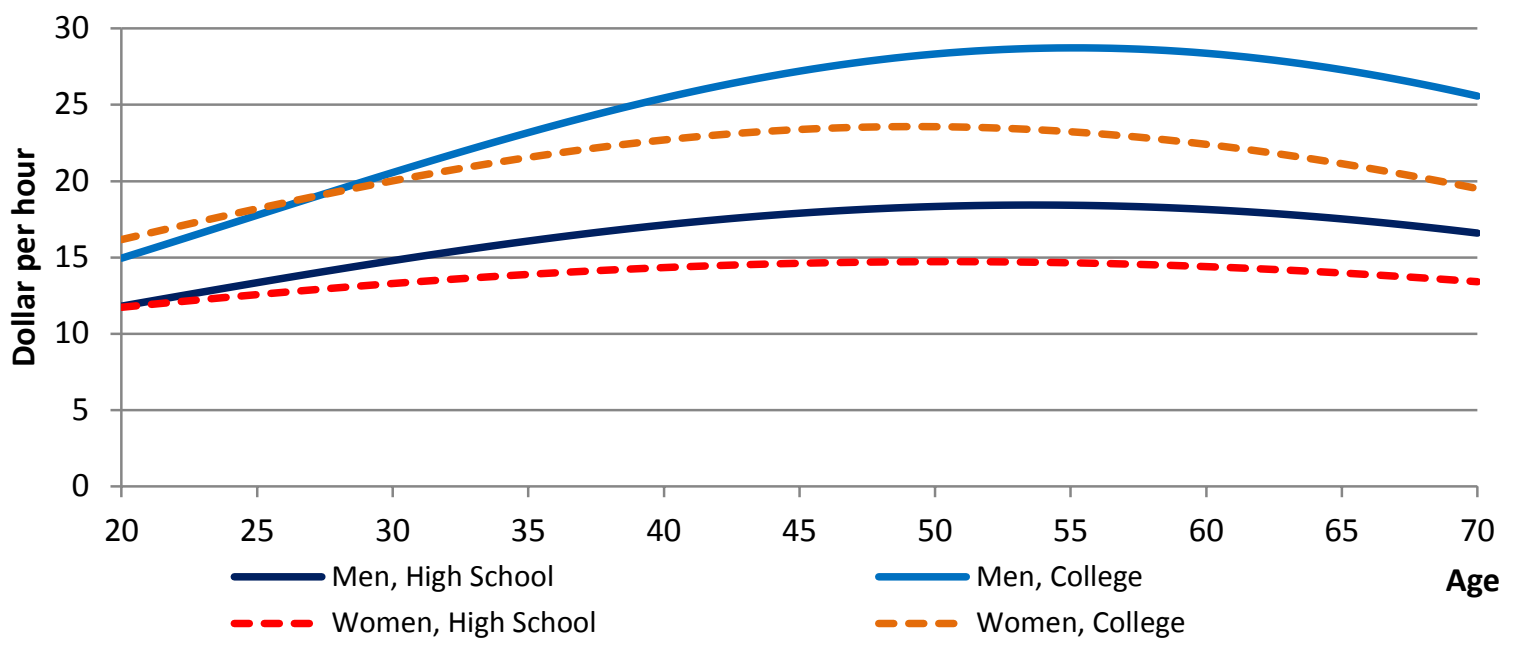

Figure 2: Hourly Wage Rate by Sex and Marital Status.

This is a graphical representation of results from the wage regression in Table 2. For the four subgroups, the mean wage in dollars per hour in dependence of age is shown for the specification of working full time, living together with a spouse, and no children under 18 present in the household. 
A

Financials (in thousand \$)

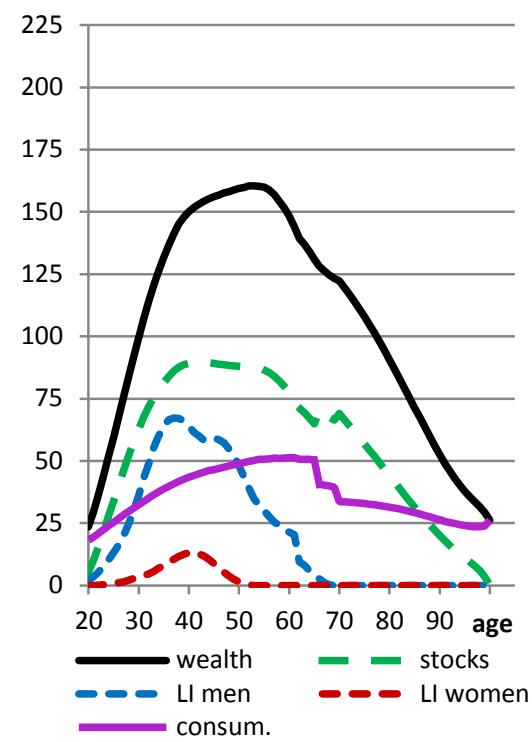

B

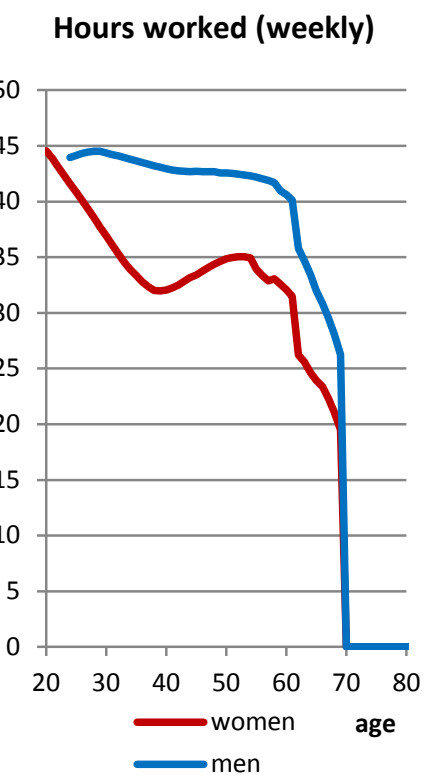

C

SoSec benefit claiming

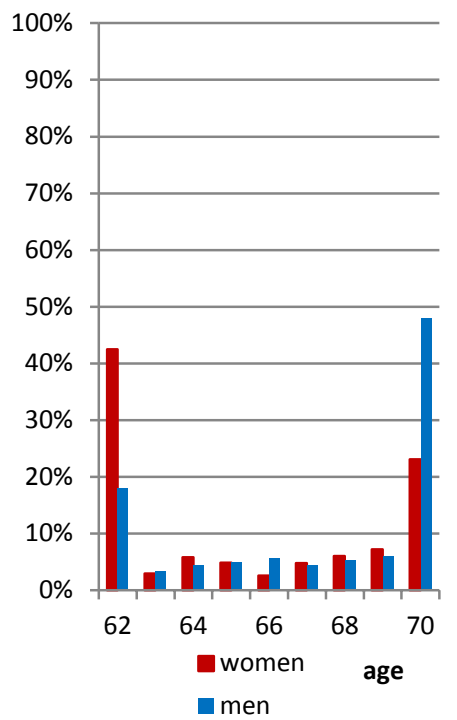

\section{Figure 3: Expected Life Cycle Profiles: Entire Population}

The three panels show simulated life cycle profiles for the complete population (singles and couples with high school or college education) at various ages: (Panel A) average levels of wealth, consumption, stock holdings, and face value of life insurance holdings (men and women); (Panel B) average work hours for men and women; and (Panel C) percentage of men and women claiming Social Security benefits at each age from 62 to 70. Averages are generated from 100,000 independent simulations. Simulation paths are based on optimal feedback controls from the baseline specification of the life cycle model. Averages for wealth, consumption and stock holdings in Panel A aggregate across men and women weighted with survival probabilities. Parameters of the model include the following: risk aversion $\gamma=5$, discount rate $\beta=0.96$, leisure preference $\alpha=0.8$, (uncertain) consumption scaling factor $\phi$ depends on family size, equity risk premium $4 \%$, initial fraction of couples $20 \%$, fraction of college education $40.3 \%$. 
A

Financials (in thousand \$)

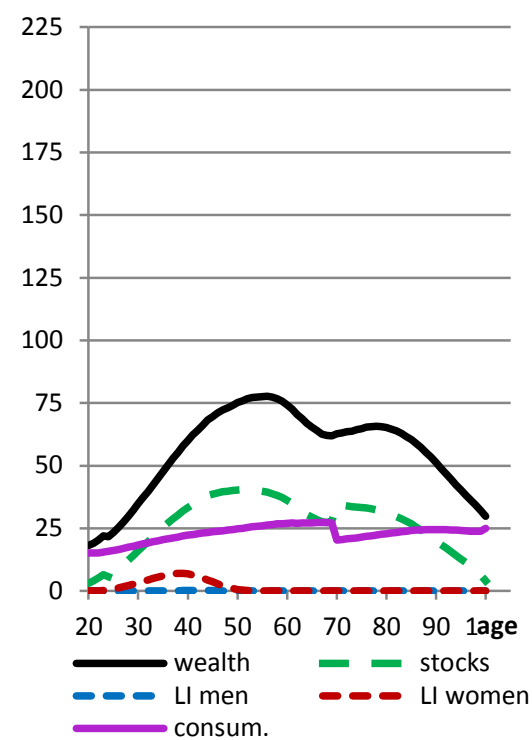

B

Hours worked (weekly)

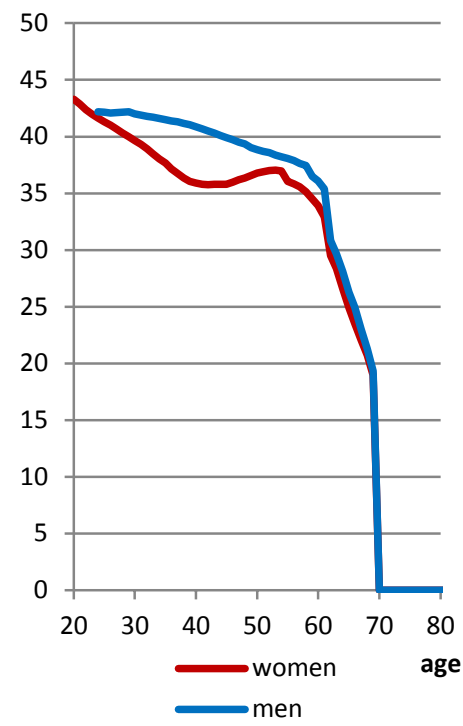

C

SoSec benefit claiming

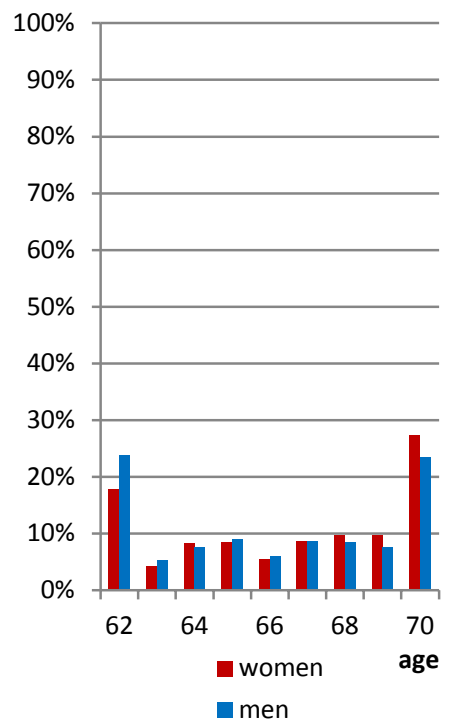

Figure 4: Expected Life Cycle Profiles: Single Men and Women

The three panels show simulated life cycle profiles for singles at various ages: (Panel A) average levels of wealth, consumption, stock holdings, and face value of life insurance holdings (men and women); (Panel B) work hours (men versus women); and (Panel C) percentage of households claiming Social Security benefits (men versus women) at each age from 62 to 70 . Averages are generated from 100,000 independent simulations based on optimal feedback controls. At each age, we extract the subgroup of singles (women or men). All reported values are calculated as (conditional) mean from the subgroup of singles. Averages for wealth, consumption and stock holdings (Panel A) aggregate across men and women. See also Figure 3. 
A

Financials (in thousand \$)

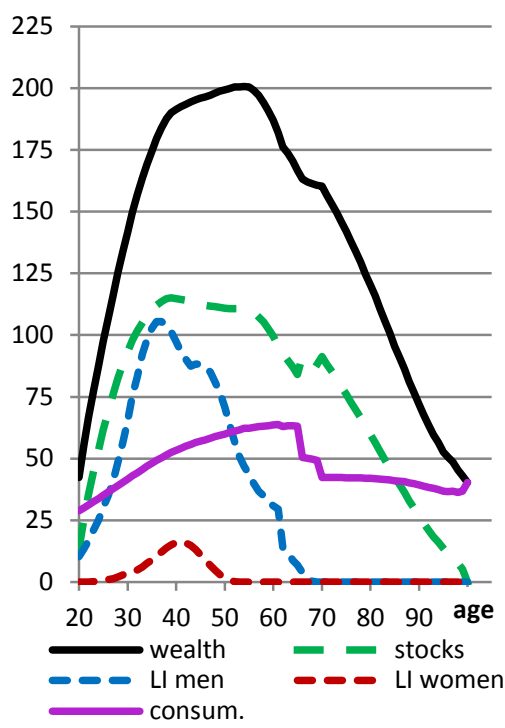

B

Hours worked (weekly)

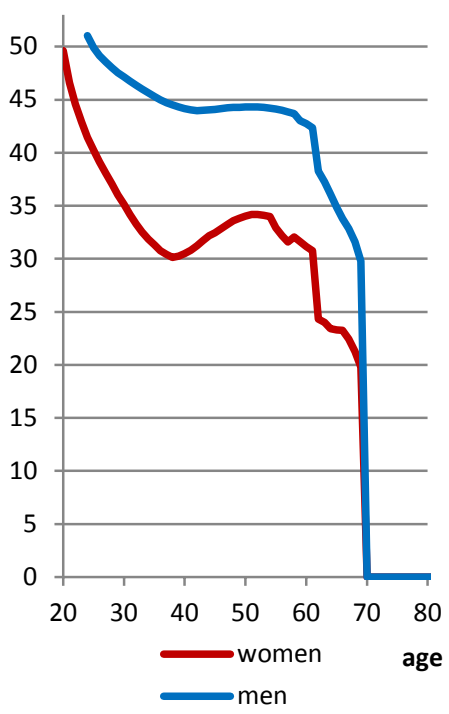

C

SoSec benefit claiming

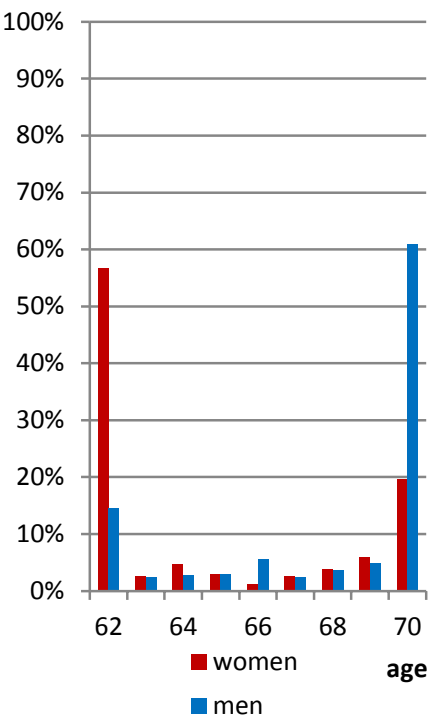

Figure 5: Expected Life Cycle Profiles: Couples

The three panels show simulated life cycle profiles for couples at various ages: (Panel A) average levels of wealth, consumption, stock holdings, and face value of life insurance holdings (men and women); (Panel B) work hours (men versus women); (Panel C) percentage of households claiming Social Security benefits (men versus women) at each age from 62 to 70 . Averages are generated from 100,000 independent simulations based on optimal feedback controls. At each age, we extract the subgroup of couples. All reported values are calculated as (conditional) mean from the subgroup of singles. Averages for wealth, consumption and stock holdings (Panel A) are reported for couples, sorted according to the wife's age. See also Figure 3. 


\section{Appendix A: Family States Modeled in Our Study}

This table shows the different family states in our model. The third column lists the states to which stochastic transitions are possible. The fourth column lists states to which transitions are possible by one or both spouses claiming retirement benefits.

\begin{tabular}{|c|c|c|c|}
\hline $\begin{array}{l}\text { State } \\
\text { number }\end{array}$ & Description & Possible stochastic transitions & $\begin{array}{l}\text { Possible claiming } \\
\text { transitions }\end{array}$ \\
\hline 1 & single woman (never married) & 1,3 & 34 \\
\hline 2 & single man (never married) & 2,3 & 35 \\
\hline 3 & couple without children & $3-4,7-8,11-12,15-16,19-20$ & $23,24-28,29-33$ \\
\hline 4 & couple with 1 child & $3-5,7-9,11-13,15-17,19-21$ & - \\
\hline 5 & couple with 2 children & $4-6,8-10,12-14,16-18,20-22$ & - \\
\hline 6 & couple with 3 or more children & $5-6,9-10,13-14,17-18,21-22$ & - \\
\hline 7 & divorced woman without children & 3,7 & 34 \\
\hline 8 & divorced woman with 1 child & $3-4,7-8$ & - \\
\hline 9 & divorced woman with 2 children & $4-5,8-9$ & - \\
\hline 10 & divorced woman with 3 or more children & $5-6,9-10$ & - \\
\hline 11 & divorced man without children & 3,11 & 35 \\
\hline 12 & divorced man with 1 child & $3-4,11-12$ & - \\
\hline 13 & divorced man with 2 children & $4-5,12-13$ & - \\
\hline 14 & divorced man with 3 or more children & $5-6,13-14$ & - \\
\hline 15 & widow without children & 3,15 & 34 \\
\hline 16 & widow with 1 child & $3-4,15-16$ & - \\
\hline 17 & widow with 2 children & $4-5,16-17$ & - \\
\hline 18 & widow with 3 or more children & $5-6,17-18$ & - \\
\hline 19 & widower without children & 3,19 & 35 \\
\hline 20 & widower with 1 child & $3-4,19-20$ & - \\
\hline 21 & widower with 2 children & $4-5,20-21$ & - \\
\hline 22 & widower with 3 or more children & $5-6,21-22$ & - \\
\hline 23 & couple with retired wife & $19,23,34$ & $29-33$ \\
\hline 24 & couple with retired husband (claimed at 66 or before) & $15,24,35$ & 29 \\
\hline 25 & couple with retired husband (claimed at 67) & $15,25,35$ & 30 \\
\hline 26 & couple with retired husband (claimed at 68) & $15,26,35$ & 31 \\
\hline 27 & couple with retired husband (claimed at 69) & $15,27,35$ & 32 \\
\hline 28 & couple with retired husband (claimed at 70) & $15,28,35$ & 33 \\
\hline 29 & retired couple (husband claimed at 66 or before) & $29,34,35$ & - \\
\hline 30 & retired couple (husband claimed at 67) & $30,34,35$ & - \\
\hline 31 & retired couple (husband claimed at 68) & $31,34,35$ & - \\
\hline 32 & retired couple (husband claimed at 69) & $32,34,35$ & - \\
\hline 33 & retired couple (husband claimed at 70) & 33, 34, 35 & - \\
\hline 34 & single retired woman & 34 & - \\
\hline 35 & single retired man & 35 & - \\
\hline
\end{tabular}




\section{Appendix B: Summary Statistics on Wealth and Work Hours for the PSID}

Besides the claiming decision, the life cycle profiles of financial wealth and work hours are the central results of our model (see Section 4.1). In the Table below, we present the corresponding empirical data from the PSID for comparison purposes. For work hours, which we also use for inferring the wages in Section 3.3, the sample is the same as from the wage calibration (waves '95 to '09) limit to observations with positive work hours excluding all unemployed persons. We use waves '99 to '09 (wealth supplement) for financial wealth and include in its definition liquid wealth (checking, savings, stocks, mutual funds, bond funds, life insurance), balances in Individual Retirement Accounts (IRA), and the household's labor income for one year. We do not explicitly model illiquid Individual Retirement Accounts, but as retirement income in our model only comprises Social Security, Individual Retirement Accounts are represented in our model as part of financial wealth. In the real world, there is a gap between the time of receiving income and consumption. In our life cycle model, we report wealth before a full year of consumption is complete, and thus annual consumption should be included in the definition of financial wealth for comparability. Nevertheless, these data are not available in the PSID, so we use annual salary as a proxy. We exclude real estate net wealth, since in our model expenditures on housing are directly subtracted from labor income and do not contribute to wealth (see Formula (10)). If a household has two or more observations in the same age bracket, we treat it as only one observation using its mean wealth over the relevant waves. Summary Statistics for Wealth Measures and Work Hour Profiles by Marital Status
and Sex, in the Panel Study of Income Dynamics. Authors' tabulations (\$2009).

\begin{tabular}{|c|c|c|c|c|c|}
\hline & \multicolumn{5}{|c|}{ Age Group } \\
\hline & $25-34$ & $35-44$ & $45-54$ & $55-64$ & $65-74$ \\
\hline \multicolumn{6}{|c|}{ Average Wealth (\$000) } \\
\hline Complete Pop. & 47.0 & 84.4 & 143.6 & 186.0 & 218.6 \\
\hline Singles & 37.7 & 47.3 & 76.3 & 82.3 & 115.8 \\
\hline Couples & 61.1 & 105.0 & 179.2 & 247.5 & 284.4 \\
\hline \multicolumn{6}{|c|}{ Average Weekly Work Hours (conditional on working) } \\
\hline \multicolumn{6}{|l|}{ Entire Sample } \\
\hline Men & 44.7 & 45.3 & 45.1 & 42.8 & 36.7 \\
\hline Women & 37.9 & 37.5 & 37.9 & 36.1 & 31.3 \\
\hline \multicolumn{6}{|l|}{ Singles } \\
\hline Men & 43.8 & 43.3 & 42.7 & 40.5 & 34.1 \\
\hline Women & 38.7 & 39.0 & 39.1 & 37.7 & 32.0 \\
\hline \multicolumn{6}{|l|}{ Couples } \\
\hline Men & 45.0 & 45.7 & 45.5 & 43.2 & 37.0 \\
\hline Women & 37.4 & 36.7 & 37.4 & 35.3 & 30.7 \\
\hline
\end{tabular}




\section{Appendix C: Additional Details on the Model Structure}

The optimization problem is homothetic in the permanent wage component $P_{t}$. To decrease computational effort, we normalize all in dollar denoted quantitites by $P_{t}$. This way the utility can be written as

$$
J_{t}\left(W_{t}, P_{t}, P I A_{t}^{x}, P I A_{t}^{y}, s_{t}\right)=\left(P_{t}\right)^{1-\gamma} j_{t}\left(w_{t}, \text { pia }_{t}^{x}, \text { pia }_{t}^{y}, s_{t}\right)
$$

and the permanent wage component is effectively eliminated as a state variable (lower case symbols denote their normalized counterparts, e.g. $w_{t}=W_{t} / P_{t}$ ). We discretize the state space $\left[w_{t}, p i a_{t}^{x}, p i a_{t}^{y}\right]$ on a 20x18x18 grid for couple family states and on a 20x18 grid for single family states. The model is solved by backward induction, as on every grid point, the optimal control variables are solved by evaluating the expectation of the future value function using Gaussian quadrature integration over the stock returns, shocks to permanent wage, and transitory wage shocks.

Regarding the calculation of the PIA, we make two simplifications to keep the model tractable. The first regards the Average Indexed Monthly Earnings which is the average over the best 35 years. Hence we would need 35 state variables (per spouse) to track the AIME correctly. In our model, the AIME is the average income in the first 35 years and after that it is only increased if the current income is higher than the previous AIME. As already mentioned, we use the PIA as a state variable instead. Let $f$ denote the concave, piece-wise linear function that converts the AIME into the PIA. Then the evolution equations for the PIA are:

$$
\begin{gathered}
P I A_{t+1}^{i}=f\left(\frac{(t-1) \cdot f^{-1}\left(P I A_{t}^{i}\right)+Y_{t}^{i}}{t}\right) \quad \text { for } t \leq 35 \\
P I A_{t+1}^{i}=\max \left(P I A_{t}^{i}, f\left(\frac{34 \cdot f^{-1}\left(P I A_{t}^{i}\right)+Y_{t}^{i}}{35}\right)\right) \quad \text { for } t>35
\end{gathered}
$$

The second problem arises from the normalization by the permanent wage component. Since all quantities denoted in dollar values are denoted in normalized dollars, the bend points in $f$ set by the Social Security rules cannot be exactly determined. For the purpose of the calculating the PIA we make the assumption that the permanent wage component is 1 (i.e., the household has an average wage rate).$^{44}$ Because of the concavity of $f$, this has the effect that the contribution of the current income $Y_{t}^{i}$ to the PIA is overestimated for households with higher permanent wage and underestimated for lower permanent wage.

In contrast to the optimization, it is easily possible to track the permanent wage component and the correct PIA without simplifications during the simulations. When comparing the correct PIA (with the permanent wage component used as a state variable) to the PIA used in the model for the simulated population, their ratio right before retirement has a mean very near to one (1.0042) and the standard deviation of the logarithm of the ratio is $13.5 \%$. This means that there is no systematic over- or underestimation caused by our assumptions and that, roughly speaking, the PIAs in our model differ, on average, by $13.5 \%$ from the actual values. Even with this approximation error, the retirement benefits captured by our model are much less distorted by shocks to permanent wage/income than in models where retirement benefits are a fixed fraction of the last year's labor income. This is because, in our model, a negative shock to permanent wage shortly before retirement would produce only a slight underestimate of this period's income to the PIA (which may be only one of 35 incomes or not considered at all, if the average is high enough). In previous models, a negative shock to permanent income directly decreases the retirement income by the same (relative) amount, which is clearly an overstatement of the actual rules.

\footnotetext{
${ }^{44}$ We make the same simplification for the retirement earnings test. The exempt amount in normalized dollars is assumed to be equal to the amount in real dollars, resulting in households with higher permanent wage being taxed too little and low wage households being taxed too much for the retirement earnings test.
} 